\title{
Earnings Quality and Foreign Investors in Gulf Cooperation Council Countries
}

\author{
Mawih Kareem Al Ani \\ Dhofar University, Accounting Department, Salalah City, Oman \\ E-Mail: mawih@du.edu.om
}

\begin{abstract}
This study aims to measure the earnings quality (EQ) in the Gulf Cooperation Council (GCC) countries using a sample of 1827 firm-year observations from 2008 to 2016 by using nine EQ measures. These measures are persistence, predictability, value relevance, earnings response coefficient (ERC), smoothness, earnings surprise, accrual quality, loss recognition timeliness and conservatism. The study also examines the effect of these nine EQ measures on attracting foreign investors. Data are collected from Capital IQ database, and some other data are calculated manually from the capital markets and firms in each country. In this quantitative research, the sample is analysed by using descriptive statistics, correlation, and generalized least squares (GLS) regression to verify the hypotheses and analyse the effect of EQ measures on attracting foreign investors. Findings show distinct effects on attracting foreign investors in different countries. Persistence, predictability, ERC, and accrual quality have a positive effect in Oman, whereas value relevance and ERC have a positive effect in Kuwait. Predictability, accrual quality, ERC, and conservatism negatively affect the Kingdom of Saudi Arabia. Finally, loss recognition timeliness, smoothness, and earnings surprise do not have any effect in all GCC countries.
\end{abstract}

Keywords: Earnings quality, Earnings quality proxies, Foreign investor, Emerging market, Gulf Cooperation Council

\section{INTRODUCTION}

In recent years, earnings quality (EQ) has become a topic of concern to analysts, creditors, managers, and other market participants owing to considerable interest in measuring the quality of financial reporting in developed and developing markets. EQ is an elusive construct, though, and people tend to understand it differently. Entwistle and Phillips (2003) defined EQ in terms of relevance and reliability of financial 
reporting, whereas Dechow et al. (2010) portrayed it as an indicator of the future of financial performance. Menicucci (2020) described EQ in the context of a specific decision model which means its meaning varies to different financial statement users. The various definitions are accepted by many researchers (An, 2017; Dechow et al., 2010; Dichev et al., 2013; Lyimo, 2014; Menicucci, 2020). The literature also has yet to reach a consensus about EQ measures. Despite the lack of widely accepted measures, the literature has established a number of EQ measures that concentrate on the specific qualities of what EQ is perceived to be.

In this regard, two streams of studies about EQ emerge. In the first stream, a considerable number of studies focus on measuring EQ (e.g., An, 2017; Dechow \& Dichev, 2002; Dichev et al., 2013; Holt, 2013; Leal et al., 2017; Lyimo, 2014; Nezlobin et al., 2019; Radzi et al., 2011). In the second stream, numerous studies provide evidence that EQ is an important common factor in many decision models such as foreign direct investment (An, 2019), excess returns (Perotti \& Wagenhofer, 2014), foreign investors (Khalil et al., 2020; Vo \& Chu, 2019), ownership structure (Ben-Nasr et al., 2015), market reaction (Ahn \& Kwon, 2010), cost of equity capital (Francis et al., 2004) and firm value (Allayannis \& Simko, 2009).

In both streams, the studies use many common EQ proxies to measure the quality of financial reporting to provide useful information for various decision-making models. Dichev et al. (2013) reported a long list of EQ measures used for different purposes. Dechow et al. (2010, p. 346) concluded that 'no single conclusion on what EQ is because "quality" is contingent on the decision context'. Licerán-Gutiérrez and CanoRodríguez (2020) pointed out that the EQ measures are not homogeneous Owing to the lack of theoretical bases of $\mathrm{EQ}$, researchers tested various measures and came up with distinct empirical results.

The second stream is more prominent than above, and many studies follow this approach. For example, An (2019) used four measures, Francis et al. (2004) used seven measures, and Perotti and Wagenhofer (2014) used eight measures. The present study belongs to the second stream as it selects nine EQ measures that are commonly used as reported by empirical literature and then examines the effect of EQ on foreign investors.

This study used nine measures for three reasons. Firstly, no study uses various proxies to measure EQ in Gulf Cooperation Council (GCC) countries. For example, Assad and Alshurideh (2020) examined three proxies (accruals) to measure EQ as mediator variables between audit quality and investment efficiency in GCC countries. Ezat et al. (2019) used three proxies, namely, accrual, predictability, and persistence, only in the Kingdom of Saudi Arabia. Shubita (2015) used income smoothing to measure EQ in GCC countries, and Alfraih and Alanezi (2015) used value relevance only in Kuwait. No comprehensive study introduces various EQ measures to provide 
useful information for stakeholders as many proxies are not addressed. Secondly, the use of different proxies is required to generalize the findings. When using such proxies, the bias in one proxy is presumed to be offset by other proxies. Thirdly, since the decrease of oil and gas prices, all GCC countries start to find other sources for revenues by diversification of the economy. As one of the main sources is attracting more foreign investments, the quality of financial reporting receives much interest.

Accordingly, this study uses nine EQ measures from two categories, namely, accounting-based and market-based measures. Perotti and Wagenhofer (2014) pointed out that accounting-based measures only use accounting earnings and their elements, whereas market-based measures are focused on accounting earnings and market returns.

From accounting-based measures, we used persistence, accrual quality, predictability, earnings smoothness, earnings surprise, and conservatism. From marketbased measures, we used value relevance, earnings response coefficient (ERC), and loss recognition timeliness.

Another classification of EQ measures was used by Ball et al. (2003) and Schipper and Vincent (2004), as cited by An (2019). In this classification, EQ is categorized by two approaches: user needs and investor protection. The concern of the user needs approach is that EQ should provide useful information to assist stakeholders in building their decision models. The measures under this approach include persistence, predictability, value relevance, and loss recognition timeliness. The second approach focuses on providing faithful information and a high level of transparency to protect investors. Conservatism, smoothness, and accruals quality are examples of this approach.

Given the many measures of EQ, Perotti and Wagenhofer (2014, p. 546) raised a question about 'how good the proxies for earnings quality really are and what the best measure in any given circumstances may be'. According to this quotation, researchers should select the measure relevant to the area of interest they want to address. To date, EQ is analysed in relation to many variables such as corporate governance, cost of capital, accounting conservatism, earnings management, stock return, excess returns, and firm value. Constructing different measures is the best solution to measure the relationship between EQ and these variables. Following Perotti and Wagenhofer (2014), the main question addressed in the present study is 'which measure has a significant effect?' Specifically, which measure has a significant effect on the foreign investor (FI)? Accordingly, this study is designed to answer the following research questions:

Q1: How to use different proxies of earnings quality to measure the quality of earnings in the non-financial firms in GCC countries?

Q2: How to assist the foreign investors in evaluating their investment in GCC countries by using different proxies of earnings quality? 
This study selected FI as a dependent variable for three reasons. Firstly, all the six GCC countries have issued new foreign investments laws (Oman, 2019; Qatar, 2019; UAE, 2018; Bahrain, 2016 [amendment]; Kuwait, 2001; the Kingdom of Saudi Arabia, 2000) (Salman \& Nobanee, 2019). These laws provide many advantages to foreign investors, such as $100 \%$ foreign-owned enterprises, tax holidays for up to 10 years and 10 -year investment visas. Increasing foreign investments is at the core of the economic diversification of GCC economies. For example, ALHarithi (2018) points out that GCC policymakers make the foreign direct investment as one of the main plans to diversify the economy in GCC countries and attract additional foreign portfolio investments. The capital markets in GCC countries encourage foreign ownerships to invest their money in these markets through enhanced monitoring, improved corporate governance, and access to credible financial information. Secondly, although few studies investigate the effect of EQ in emerging markets, such as GCC markets (e.g., Al-Amri et al., 2017; Alfraih \& Alanezi, 2015; Ezat et al., 2019; Shubita, 2015), the role of EQ in attracting foreign investors remains unexplored in the current literature. Thirdly, International Monetary Fund classified GCC markets as weak corporate governance and, as such, they need improvement to protect foreign investors.

ALHarithi (2018) found determinants related to foreign investments in GCC countries, such as inflation, laws and regulations, and accountability. Elheddad (2018) found that political instability is the most important determinant affecting foreign investments. These studies conclude a good opportunity for GCC markets to attract foreign investments. These determinants may equip foreign investors with stronger incentives to protect their investments. In addition, these studies point out that improvement in corporate governance, stronger foreign investment laws, stronger accountability, and access to credible financial information have a positive effect on attracting foreign investors. To the best of our knowledge, no studies examine the effect of EQ on attracting foreign investors in GCC countries. To fill this gap, this study examines the relationship between a firm's EQ and foreign ownership in the context of GCC countries, an important emerging market. Naturally, whether EQ influences foreign investors in GCC countries must be addressed.

The Gulf Cooperation Council (GCC) countries include Bahrain, Kuwait, Oman, Qatar, Saudi Arabia, and the United Arab Emirates. The GCC countries share a common economy, culture, social background, politics, language, and religion. The economies of GCC countries are highly reliant on the oil sector. The GCC is a fast-growing regional union, and all its members have had "vision" for twenty or thirty years. They have also issued Corporate Governance Code-CGC in 2006 (except for Oman which has implemented the code in 2002) (Shehata, 2015). In all visions of the GCC countries, 
the importance of economic diversification is accentuated, which is one of the most attractive topics in these visions. Khayat (2020) indicates that the GCC countries have started to implement a policy of economic diversification.

This study has two main objectives. The first objective is to measure the EQ of the six GCC countries using a sample of 1827 firm-year observations from 2008 to 2016. Examining EQ by using proxies containing one-dimensional angles may lead to insufficient conclusions. To address this shortcoming, we used nine proxies to measure EQ. The second objective is to examine the effect of various EQ measures so as to give current foreign investors a good opportunity to assess their investments and build a reliable decision model about these investments and attract more foreign investments through the EQ measures.

\section{LITERATURE REVIEW AND HYPOTHESIS DEVELOPMENT}

Researchers have yet to reach a universally agreed definition of EQ. The definition varies because EQ is important for many financial statement users, such as investors, analysts, managers, and other stakeholders. The many definitions of EQ are based on the perspective of the users.

Penman and Zhang (2002) defined EQ as a measure for future earnings in relation to future earnings. The main issue of this definition is that EQ is used to predict future earnings. The definition is also referring to the consistency of using accounting methods which leads to improving EQ.

EQ is discussed in the frame of firm performance as reported earnings are used to predict the future performance of a firm (Chan et al., 2006). According to Francis et al. (2004), EQ is used to extract value-relevant information from the earnings trend. Radzi et al. (2011) defined EQ in the frame of characteristics of useful financial information; reliability and relevance. An (2017) pointed out that investors use EQ for contracting purposes.

Leal et al. (2017) discussed that most of the studies on EQ seek to provide valuable information for stakeholders about EQ and reduce uncertainties in the capital markets. Therefore, the content of information presented in financial statements is an essential source of relevance and reliability.

As per the International Financial Reporting Standards (IFRS) conceptual framework, relevance and reliability or faithful representative are the most important qualitative characteristics of financial reporting. Relevance means that information has predictive value in the future and is related to decision usefulness, whereas reliability means complete, neutral, and free from error and is related to accountability. An (2017) indicated that EQ is measured with these two types of approaches. The first approach focuses on the quality of financial reporting as EQ is associated with the relevance of 
the financial information and measured by earnings persistence and value relevance. The second approach, i.e., accountability, is related to the reliability of financial information and measured by conservatism and accruals quality. Perotti and Wagenhofer (2014) and Vo and Chu (2019) used two types of approaches: accountingbased and market-based measures. Accounting-based measures only use accounting earnings and their elements, whereas market-based measures focus on accounting earnings and market returns. The study of An (2019), Perotti and Wagenhofer (2014) and Vo and Chu (2019) are useful for this study. Perotti and Wagenhofer (2014) used eight EQ proxies: persistence, predictability, smoothness (two proxies), abnormal accrual, accrual quality, ERC, and value relevance. This study is also close to Perotti and Wagenhofer (2014) in using many different EQ proxies. Vo and Chu (2019) uses only two measurements of EQ, namely, accounting measure (earnings management and earnings persistence) and market measure (earnings informativeness). An (2019) uses four proxies: persistence, conservatism, value relevance, and accruals quality. On the other side, the study of An (2019) and Vo and Chu (2019) are close to our study in terms of using the variable of foreign investors.

This study uses nine measures of EQ to predict the behaviour of foreign investors, allowing them to assess EQ using different proxies and to give a clear picture of the investment decision.

The main issue with EQ is how to measure it and how to interpret the result of this measure in terms of predicting the behaviour of foreign investors. The literature lists different proxies for measuring EQ (An, 2017, 2019; Dechow et al., 2010; Lyimo, 2014; Perotti \& Wagenhofer, 2014; Radzi et al., 2011). This study uses nine proxies of EQ due to the availability of data of our sample and useful interpretation of the relationship between EQ and foreign investors. The following hypotheses are based on each measure.

\section{Persistence}

Persistence is a commonly used measure of EQ. It means how much of the present earnings can remain and continue from time to time in the future. More stable earnings are more sustainable and of high quality, whereas earnings that are less stable are considered more transitory and of less quality (An, 2017).

Firms with more persistent earnings have more 'sustainable' earnings, which are more useful for predicting future earnings. Perotti and Wagenhofer (2014) found that investors use persistence because high persistence has a positive relationship with high EQ as it implies a reliable, continuous, and less volatile earnings generation mechanism that investors especially value. Ben-Nasr et al. (2015) found that foreign ownership is associated with higher EQ in terms of persistence as foreign investors prefer to invest their money in firms with higher earnings in the future. 
The criterion used to interpret EQ is the value of $\beta$ in the regression model of persistence as it is close to highly persistent earnings, whereas the value close to zero indicates highly unsustainable earnings. In GCC countries, foreign ownership is less than domestic ownership, but GCC markets are expected to attract more foreign ownership by improving EQ and sowing more persistence. An (2019) stated that doing so helps foreign ownership invest more in firms with higher EQ.

\section{H1: Highly sustainable EQ attracts foreign ownership.}

\section{Predictability}

Predictability tests the ability of recorded earnings to predict future earnings or operating income components (Penman \& Zhang, 2002). More predictability reflects high-quality earnings, but low predictability suggests low-quality earnings. Financial statements are the main source of information, and predictability is one of the most important characteristics of financial statements, which help investors assess the ability of firms to survive and succeed. Therefore, the predictive value of information gives investors a good indicator of the quality of financial reporting.

Perotti and Wagenhofer (2014) found that predictability has a positive EQ because it improves the precision of earnings prediction. In addition, Lee and Kim (2019) found a positive association between earnings and predictability in terms of generating positive long-term cash flow in the future, which are more useful for investors.

The credibility of financial statements is one of the most important challenges of financial reporting in GCC countries. Assad and Alshurideh (2020) pointed out that the GCC markets are characterized by unreliable financial reporting and low investor protection. Positive predictability is the critical form of data available to investors and other participants of markets. According to this discussion, we expect that improving the credibility of financial reporting and EQ will attract more foreign investors.

\section{H2: High predictability of EQ attracts foreign ownership.}

\section{Value Relevance and ERC}

Hellström (2006), as cited by Mirza et al. (2019), defined value relevance as the relationship between firm market value and accounting information. Barth et al. (2001) pointed out that value relevance is a practical concept of relevance determined by FASB. Most of the researchers (e.g., Adetunji, 2016; Barth et al., 2001; Mirza et al., 2019) agreed that relevant accounting information is the information that has the ability to reflect the firm value or share price.

Chandrapala (2013) examined EQ in Colombo by using value relevance, book value, and return on share price and found a negative association between book value and earnings. An (2017) measured EQ in Korea by using value relevance as the 
explanatory power of earnings and book value, and share price. Dechow et al. (2010) used ERC to measure EQ which is measured by $\beta$ value, whereas value relevance is the explanatory power of coefficient of determination $\left(\mathrm{R}^{2}\right)$ as large (small) $\mathrm{R}^{2}$ indicates more (less) value-relevant EQ.

Perotti and Wagenhofer (2014) discussed that value relevance is a good indicator to measure the informativeness of financial reporting, which lead to improving EQ as more informative components of earnings will have a higher ERC, which means that high-value relevance has a positive relationship with the quality of financial reporting. Maditinos et al. (2013) pointed out that ERC is an important indicator from the perspective of investors as it informs them about the market reaction to the accounting data. Jiang and Kim (2004) found that foreign investors prefer to invest in an environment with high informational advantages and low information asymmetry to enhance their informational advantages about their investment. Choi et al. (2013) pointed out that an increase in foreign ownership leads to increased demand and pressure for increased informational content by domestic firms, resulting in higher value relevance of financial reporting. An (2019) points out that the value relevance in terms of the explanatory power of earnings, book value, and the share price has a positive relationship with foreign investors because they want to protect their wealth, reduce monitoring costs, and monitor firms. Therefore, higher foreign investor ownership induces firms to improve transparency and to decrease opportunistic choices and decisions of the managers. Accordingly, this study expects that the relationship between value relevance and foreign ownership is positive.

\section{H3a: High value relevance of EQ attracts foreign ownership. H3b: The high ERC of EQ attracts foreign ownership.}

\section{Earnings Surprise Indicator}

Earnings surprise indicator (ESI) is a case of reported earnings that are above or below the expected earnings by analysts. ESI is a good indicator to predict a firm's earnings behaviour (Okoro \& Ofor, 2019). The level of earnings surprise works as a function of managers' previous recognition and measurement decisions of the firm. Barton and Simko (2002) argued that earnings surprise is a good indicator of EQ because it indicates managers' biased estimates and judgments about earnings and net assets. Basically, managers have many incentives to bias earnings and avoid negative earnings surprises. Firstly, firms use 'meeting or beating analysts' earnings forecasts' as an incentive to manage earnings and avoid negative earnings surprises. Barton and Simko (2002, p. 2), found that investors use earnings surprises to investigate 'the pressure imposed on management to meet analysts' earnings projections'. Secondly, Matsumoto (2002) argued that high institutional ownership, the increased value 
relevance of earnings, and greater reliance on implicit claims by stakeholders are the important reasons that drive firms to take actions to avoid negative earnings surprises.

Barton and Simko (2002) reported that a large ratio of earnings surprise indicates poor EQ, whereas a small ratio indicates high EQ. Poor EQ indicates that the investors will not show any interest in the investments in such business while they focus on the investments in the business where the ESI is small, and EQ is high. This indicator gives the investors a positive signal about EQ of the firms, which as the investors tend to decide on investments based on this indicator. In GCC countries, many investors rely on analysts' earnings forecasts to build their decision models. The study expects that firms'/markets' earnings surprise is a good indicator of EQ, giving foreign investors more information. Therefore, this study expects a positive relationship between small ESI and foreign ownership.

\section{H4: Small ratio of earnings surprise will attract more foreign ownership.}

\section{Accrual Quality}

The earnings reflect future cash flows when accruals quickly convert into cash (Dechow \& Dichev, 2002). The difference between accounting earnings and cash flows from the operating activities of a firm is referred to as accrual quality. As decided by Desai et al. (2006), the operating accrual used to measure EQ does not include accruals resulting from investing and financing activities. According to Dechow et al. (2010), the two types of measures of accruals are the magnitude of accruals and residuals from accrual models. In the first type, the low magnitude of accruals should be less to convert earnings into cash quickly. In the second type, the residual should be also less to reflect low estimation error. The standard deviation of residuals is a measure of EQ as less residual means higher quality. As the other participant in the market, foreign investors prefer less accrual for three reasons. Firstly, they prefer less accrual because less accrual quality mitigates the firm's risks of future cash flows and earnings (Shin \& Oh, 2017). Secondly, participants in the market, including foreign investors, prefer quick conversion of accruals into cash, as foreign investors tend to decide on their investments based on operating cash flow in predicting future cash flow (Lee \& Kim, 2019). Thirdly, Dechow and Dichev (2002) pointed out that earnings will be more representative and informative of future cash flows when accruals contain lower estimation error. Therefore, this study expects a positive relationship between the quick conversion of accruals into cash (low residual) and foreign ownership.

\section{H5: Low residual of accrual quality attracts foreign ownership.}

\section{Earnings Smoothness}


Allayannis and Simko (2009) defined earnings smoothness as a reduction of volatility in the earnings as reported in the financial statements. Earnings smoothness is measured as the ratio of the standard deviation of earnings to the standard deviation of cash flows. The literature presents two different points of view regarding the desirability and interpretation of earnings smoothness. The first view is that lower smoothness indicates good EQ (Francis et al., 2004), and it is a desirable practice because the smoothness of earnings narrows down the gap between earnings and cash flow and provides good forecasting information. In the second point of view, lower smoothness refers to lower EQ (Leuz et al., 2003), and it is not a desirable practice because earnings smoothness is considered a consequence of earnings management (Perotti \& Wagenhofer, 2014). Nezlobin et al. (2019) presented evidence from the literature that the first point of view is more acceptable and used by the researchers than the second one.

Cheng and Li (2014) argue that earnings smoothness improves EQ because it improves earnings informativeness. Improved earnings informativeness means that the firms have rich information, making the market an environment with rich information wherein investors can utilise all available information to build a good decision model about their investment.

As mentioned earlier, the GCC market is classified as a less informative environment, so foreign investors are unable to interpret earnings smoothness as a good indicator of EQ. We thus expect earnings smoothness not to attract foreign investors to invest in the GCC market.

\section{H6: High earnings smoothness does not attract foreign ownership.}

\section{Loss Recognition Timeliness}

Loss recognition timeliness is an important measure of EQ. Bissessur (2008) suggested that losses may impact capital markets as the efficient functioning of these markets will improve through high levels of information asymmetry. The use of accruals for loss recognition timeliness for firms mitigates this problem by incorporating losses in a timely manner, thus reducing uncertainty about firms' futures.

The more timely the recognition of losses, the higher the EQ has a positive effect on EQ because recognising losses on a timely basis, as Ball and Shivakumar (2005) suggested. Dobre et al. (2015) also argued that loss recognition timeliness gives shareholders, including foreign investors, more confidence about financial reporting in the market because timely loss recognition means the size of earnings management done by the managers can be mitigated. Dechow et al. (2010) pointed out that the investors and financial analysts require loss recognition timeliness is to curb the management's 
natural optimism. I expect that using loss recognition timeliness as an indicator of EQ in GCC markets will attract more foreign investors.

\section{H7: Loss recognition timeliness attracts foreign ownership.}

\section{Conservatism}

Basu (1997, p.4) defined accounting conservatism as 'the quicker recognition of bad news in earnings than good news' and devised several tests. Most of the studies in this area used the same definition as Basu (1997), but these studies reached mixed results about the association between EQ and conservatism.

Strong evidence suggests that accounting conservatism has a positive effect on EQ. Watts (2003a), Kim et al. (2013), and Zhong and Li (2017) explored the opportunistic behaviour of managers on accounting conservatism and EQs, and they found a strong relationship between AC and EQ. Shubita (2015) concluded that income smoothing improves EQ in the GCC countries. With respect to the relationship between EQ and foreign investors, Khalil et al. (2020) found that foreign investors demand conservative reporting of earnings. Ferreira et al. (2017) reached the same conclusion regarding the foreign investors' preference for conservative reporting of earnings because they have informational disadvantage. Foreign investors cannot access the data as their domestic peers, so they are more careful about financial statements. In GCC countries, all listed firms use IFRS to prepare financial statements; therefore, accounting conservatism practices are less followed by these firms. For example, Hamdan et al. (2011) pointed out that the Kuwaiti capital market authority forces listed firms to keep a reasonable level of conservatism. I expect that using conservative financial reporting will not affect foreign ownership.

\section{H8: Using accounting conservatism practices does not attract foreign investors.}

Table 1 summarizes the nature of relationships between EQ and foreign investors according to our hypotheses. 
Table 1 Nature of Relationships between EQ Measures and Foreign Investors

\begin{tabular}{l|ccc}
\hline \multicolumn{1}{c|}{ EQ proxy } & $\begin{array}{c}\text { Nature of } \\
\text { Relationship }\end{array}$ & $\begin{array}{c}\text { Expected } \\
\text { Relationship }\end{array}$ & Reference \\
\hline Persistence & Positive & + & $\begin{array}{c}\text { Ben-Nasr et al. (2015), } \\
\text { Perotti \& Wagenhofer (2014) }\end{array}$ \\
\hline Predictability & Positive & + & Lee \& Kim (2019) \\
\hline Value Relevance & Positive & + & An (2019), Jiang \& Kim (2004) \\
\hline ERC & Positive & + & Maditinos et al. (2013) \\
\hline Earnings Surprise & Positive & + & Barton \& Simko (2002) \\
\hline Accrual Quality & Positive & + & $\begin{array}{c}\text { Lee \& Kim, 2019), } \\
\text { (Shin \& Oh, 2017). }\end{array}$ \\
\hline Earnings Smoothness & Positive & No sign & Cheng \& Li (2014) \\
\hline $\begin{array}{l}\text { Timely Recognition } \\
\text { Loss }\end{array}$ & Positive & + & $\begin{array}{c}\text { Dechow et al. (2010), } \\
\text { Dobre et al. (2015) }\end{array}$ \\
\hline Conservatism & Negative & No sign & $\begin{array}{c}\text { Hamdan et al. (2011), } \\
\text { Khalil et al. (2020) }\end{array}$ \\
\hline
\end{tabular}

\section{METHODOLOGY}

\section{Sample Selection}

The sample in the study consists of listed firms on the GCC exchange stock markets. The GCC countries include Bahrain, Kuwait, Oman, Qatar, the Kingdom of Saudi Arabia, and the UAE. This study used secondary data which were collected from Capital IQ database from 2008 to 2016 . Other data were calculated manually from the capital markets and firms in each country. Table 2 shows that the total number of firms in this study is 683 . This study excludes 326 banking and financial institutions due to both organisations' different rules and regulations. It also excludes 15 non-financial firms under liquidation (losses $75 \%$ of capital) and 145 non-financial firms with missing data for some variables. Accordingly, the final sample of the study includes 1827 firmyear observations.

Table 2 Sample Distribution by Country

\begin{tabular}{l|ccccccc}
\hline & KSA & OMN & QAT & BAH & KUW & UAE & Total \\
\hline Total Listed Firms (1) & 171 & 107 & 43 & 42 & 173 & 147 & 683 \\
\hline Financial firms (2) & 50 & 31 & 17 & 24 & 118 & 86 & 326 \\
\hline Non- Financial firms 3 (1-2) & 121 & 76 & 26 & 18 & 55 & 61 & 357 \\
\hline Firms with losses (4) & 4 & 0 & 0 & 0 & 11 & 0 & 15 \\
\hline Firms with missing data (5) & 39 & 10 & 12 & 9 & 35 & 34 & 139 \\
\hline Number of firms in sample 6 (3-4-5) & 78 & 66 & 14 & 9 & 9 & 27 & 203 \\
\hline Number of observations 6*(9 years) & 702 & 594 & 126 & 81 & 81 & 243 & 1,827 \\
\hline
\end{tabular}


The data are processed in two stages. In the first stage, I measure the EQ by using nine proxies, and in the second stage, the models of the association between EQ and FI are tested in all GCC countries.

\section{Data}

The study required sufficient data to calculate all nine EQ proxies for each firm and in each country in a sample. To avoid excluding too many firms from the sample, we did not require data availability for each firm over the full nine-year period and for the nine EQ proxies. Accordingly, the composition of observation in the samples varies. The total sample includes 1827 firm-year observations, and the number of observations in each measure is different. For example, in calculating the conservatism measure, the number of observations (number of firms * 9 years) in KSA is 758; Oman, 724; Qatar, 119; Bahrain, 69; Kuwait, 60; UAE, 219, whereas in calculating the persistence of earnings, the number of observation is $760,726,120,71,63$, and 221 , respectively. These differences in the number of observations among the EQ proxies are because some data are missing when I calculate some of the EQ proxies. Most of the variables are measured by the currency of each country. Given the differences between these currencies, we converted the unit of these variables into an algorithm. Owing to the nature of data, GLS - panel data random effect regression model was used to estimate the association between EQ and FI. This study uses GLS- random effect without calculating the value of Hausman test (as a criterion between random effect and fixed effect) due to the flowing facts. Firstly, according to Greene (2000), if the sample was extracted from a large population (such as listed firms on the GCC in this study), individual-specific constant terms are regarded as randomly distributed across crosssectional firms. Secondly, Greene (2000) suggests that a Hausman test which is normally used to choose between fixed effect and random effect, becomes problematic when using unbalanced panels, as the case in this study. For example, there are around 594 observations in Oman, whereas the number of observations is 81 in Bahrain. Therefore, this study employs random-effect regression (RE) to test robustness. Thirdly and finally, Bell et al. (2019) prefer to use random effects in multilevel analyses as it allows the researcher to extend the analysis by using random slopes and distinct within and between effects which cannot be as effectively implemented under a fixed effect.

\section{Model Specifications}

This study has two main objectives. The first one is to measure EQ by using nine different proxies. The second objective is to find the effect of the different proxies of EQ on attracting foreign investors. For these purposes, this study constructs the following models for measuring EQ in GCC countries: 


\section{Model 1: Persistence:}

Following Perotti and Wagenhofer (2014), persistence is measured as the slopecoefficient $\beta$ as expressed in the following equation:

$$
E Q(P R E) \text { it }=a+\beta E \text { arningsit }-1+\text { cit }
$$

Where for firm $\mathrm{i}$ and year $\mathrm{t}, \alpha$ is Constant, $\beta$ is Beta, Earnings $\mathrm{s}_{\mathrm{it}}$ is the net income before extraordinary items in the current year; Earningsit-1 is earnings before extraordinary items in the previous year; $\varepsilon_{\mathrm{it}}$ is the residuals. When the value of $\beta$ is close to one, EQ is high; close to zero, low EQ.

\section{Model 2: Predictability:}

Again following Perotti and Wagenhofer (2014), predictability is the $\mathrm{R}^{2}$ of regression of EQ (PRE) as in Equation 1. $\mathrm{R}^{2}$ (coefficient of determination) is the explanatory power of the regression. More predictability means high EQ; low predictability, low EQ.

\section{Model 3: Value Relevance:}

We used two proxies to measure value relevance. The first proxy follows Perotti and Wagenhofer (2014). The value relevance is measured by the following equation:

$$
E Q(V R i, t)=\alpha+\beta E i, t / P i, t+\varepsilon i, t
$$

Where for firm $i$ and year $t, \alpha$ is Constant, $\beta$ is ERC, $P_{i, t}$ is the share closed price at the end of the year; $\mathrm{E}$ is the earnings before extraordinary items in the previous year; $\varepsilon_{\mathrm{i}, \mathrm{t}}$ is the residuals. The value relevance is the ERC which is the $\beta$ in the equation. Large $\beta$ indicates more value-relevant EQ; less $\beta$, less value-relevant EQ.

Following Ali and Hwang (2000), the second proxy that we used is the relationship between earnings, book value, and share price. The value relevance is the explanatory power of $\mathrm{R}^{2}$ of earnings and book value of equity for stock returns as in the following equation:

$$
P i, t=\alpha+\beta 1 B V i, t+\beta 2 E P S i, t+\varepsilon i, t
$$

Where for firm $i$ and year $t, \alpha$ is Constant, $\beta$ is Beta, $P_{i, t}$ is the stock price at the end of the year; $\mathrm{BV}_{\mathrm{i}, \mathrm{t}}$ is the book value of the stock at the end of the year; $\mathrm{EPS}_{\mathrm{i}, \mathrm{t}}$ is the earnings per share at the end of the year; $\varepsilon_{i, t}$ is the residuals. Large $\mathrm{R}^{2}$ indicates more valuerelevant EQ; less $\mathrm{R}^{2}$, less value-relevant $\mathrm{EQ}$.

Following the prior studies (e.g., Adetunji, 2016; Perotti \& Wagenhofer, 2014; Ragab \& Omran, 2006), this study uses two proxies to measure VR as the two proxies give a comprehensive picture about the market reaction to accounting data. 
Model 4: ESI:

Following Barton and Simko (2002), the equation of earnings surprise is Earnings Surprise Indicator $=$ net operating assets at beginning / total sales

$$
E Q(E S I) i t=\frac{S E i t-C M S i t+T D i t}{T S i t}
$$

Where ESI is earnings surprise indicator, SE is shareholder equity, CMS is cash and market securities, TD is total debts, and TS is total sales. The smaller the earnings surprise, the higher the EQ; the greater the earnings surprise, the poorer the EQ.

\section{Model 5: Accrual Quality:}

Following Dechow and Dichev (2002), the equation below is used to measure the residual of accrual quality:

$$
E Q(V W C i, t)=\alpha+\beta 1 C F O i, t-1+\beta 2 C F O i, t+3 C F O i, t+1+\varepsilon i, t
$$

Where for firm $\mathrm{i}$ and year $\mathrm{t}, \alpha$ is Constant, $\beta$ is Beta, VWC is the variation of working capital, CFO stands for operating cash flow in the current year, CFO-1 is operating cash flow in the previous year, and $\mathrm{CFO}+1$ is operating cash flow in the future year. A low residual of regression indicates high EQ, and a high residual of regression means poor EQ.

\section{Model 6: Earnings Smoothness:}

Following Dechow et al. (2010), the equation of earnings smoothness which is used to measure the EQ is

$$
E Q(S M i t)=\frac{S D \text { of Earningsit }}{S D \text { of cash flowit }}
$$

Where SM is earnings smoothness; SD, standard deviation. Lower smoothness indicates good EQ; higher smoothness indicates poor EQ.

\section{Model 5: Loss Recognition Timeliness:}

Following Dechow et al. (2010), loss recognition timeliness is measured in Equation 7.

$$
E Q(\mathrm{TRL}) \mathrm{it}=\alpha+\alpha 1 \mathrm{Dt}+\beta 0 \operatorname{Ret} t+\beta 1 \mathrm{Dt} * \operatorname{Ret}_{t}+\varepsilon \mathrm{i}, t
$$

Where $\mathrm{Dt}=1$ if $\operatorname{Rett}<0$; otherwise, $0 . \alpha$ is Constant, and higher $\beta 1$ implies more timely recognition of the incurred losses in earnings.

Model 8: Conservatism:

Following Ball and Shivakumar (2005), we measured conservatism as the relationship between accruals and negative cash flows over the association between accruals and cash flows. 


$$
\frac{E Q(\text { Con }) i t}{\text { TAit }}=\alpha+\beta 1 \frac{\text { NCFOit }}{\text { TAit }}+\beta 2 \frac{\text { CFOit }}{\text { TAit }}+\beta 3 \frac{\text { NCFOit }}{\text { TAit }} * \frac{\text { CFOit }}{\text { TAit }}+\varepsilon \mathrm{i}, t(8)
$$

Where for firm $\mathrm{i}$ and year $\mathrm{t}, \alpha$ is Constant, EQ $(\mathrm{Con})_{\mathrm{i}, \mathrm{t}}$ is the earnings; $\mathrm{NCFO}_{\mathrm{i}, \mathrm{t}}$ is a dummy variable which takes 1 if $\mathrm{CFO}_{i, t}$ is negative; otherwise, 0 ; $\mathrm{CFO}$ is operating cash flows; $\varepsilon_{i, t}$ is the residuals. The degree of conservatism is the value of the incremental coefficient ( $\beta 3$ ) from Equation 8. The larger (smaller) the value of the incremental coefficient $(\beta 3)$ is, the more (less) conservative the earnings are.

\section{Measuring Foreign Investors}

Following An (2019), FI is the percentage of equity shares held by all foreign investors by the end of the year, and it is calculated as the total number of shares held by FI over the total number of shares outstanding.

The study uses the below regression models to investigate whether EQ through different proxies plays an active role in attracting more foreign investors. To make the analysis robust, we used three control variables which are named in prior studies (e.g., An (2019); Perotti and Wagenhofer (2014); Vo and Chu (2019)). These variables are firm size (S), auditor type (Big4), and leverage (R). Firm size is measured by the algorithm of total assets. Auditor type is measured by big 4 and non-big 4 audit firms. Leverage is measured by total assets divided by total liabilities.

Model 1: Persistence (EQ-PER) and FI

$$
\text { FIit }=\alpha+\beta 1 E Q(P E R) i t+\beta 2 \text { Sit }+\beta 3 \text { Big } 4 i t+\beta 4 R i t+\varepsilon \mathrm{it} \quad(1-1)
$$

Model 2: Predictability (EQ-P) and FI

$$
\text { FIit }=\alpha+\beta 1 E Q(P) i t \beta 2 \text { Sit }+\beta 3 B i g 4 i t+\beta 4 R i t+\varepsilon i t
$$

Model 3: Value relevance (EQ-VR) and FI

$$
\text { FIit }=\alpha+\beta 1 E Q(V R) i t \beta 2 \text { Sit }+\beta 3 B i g 4 i t+\beta 4 \text { Rit }+\varepsilon i t
$$

Model 4: ERC (EQ-ERC) and FI

$$
\text { FIit }=\alpha+\beta 1 E Q(E R C) i t \beta 2 \text { Sit }+\beta 3 \text { Big } 4 i t+\beta 4 R i t+\varepsilon i t
$$

Model 5: Loss recognition timeliness (EQ-TRL) and FI

$$
\text { FIit }=\alpha+\beta 1 E Q(\text { TRL }) i t \beta 2 \text { Sit }+\beta 3 \text { Big } 4 i t+\beta 4 R i t+\varepsilon i t
$$

Model 6: Accrual quality (EQ-AQ) and FI 


$$
\text { FIit }=\alpha+\beta 1 E Q(A Q) i t \beta 2 \text { Sit }+\beta 3 B i g 4 i t+\beta 4 R i t+\varepsilon i t
$$

Model 7: Earnings smoothness (EQ-SM) and FI

$$
\text { FIit }=\alpha+\beta 1 E Q(S M) i t \beta 2 \text { Sit }+\beta 3 \text { Big } 4 i t+\beta 4 \text { Rit }+ \text { cit }
$$

Model 8: ESI (EQ-ESI) and FI

$$
\text { FIit }=\alpha+\beta 1 E Q(E S I) i t \beta 2 \text { Sit }+\beta 3 \text { Big } 4 i t+\beta 4 \text { Rit }+ \text { cit }
$$

Model 9: Conservatism (EQ-CON) and FI

$$
\text { FIit }=\alpha+\beta 1 E Q(C O N) i t \beta 2 S i t+\beta 3 \text { Big } 4 i t+\beta 4 \text { Rit }+ \text { cit }
$$

Note. $\mathrm{i}=$ firm, $\mathrm{t}=$ year, $\alpha=$ constant, $\beta=$ beta

\section{EMPIRICAL RESULTS}

This section has two subsections: results of measuring EQ and regression results between each measure and FI. As discussed earlier, each measure of EQ has different variables, so the results of descriptive statistics of each measure are presented along with the measure itself. To maximize the benefit of the results, we present the results of measuring EQ and its effect on FI together. Only the descriptive statistics of control variables and dependent variables are presented in the beginning. Descriptive statistics are used to describe data using numbers or statistical measures that may best represent all data collected during research and give a good picture of the sample. The mean tells the average value, which is a perfect representative figure for the data set to ensure that there are no extreme values in the data set. Also, standard deviation estimates the degree to which the value of a particular variable deviates from the mean (Vanlalhriati \& Singh, 2015). Also, the value of standard deviation is used to measure the value of EQ in terms of smoothness. Correlation and regression are used in this study. Correlation is used to find the association between the EQ and FI, and regression is used to examine the effect of EQ on FI. In the regression model, GLS - panel data random effect regression model is used to examine the effect of EQ on FI. In some of the EQ proxies, such as predictability and value relevance, the result is dependent on the value of $\mathrm{R}^{2}$ to determine whether the EQ is high or low. For example, a high value of $\mathrm{R}^{2}$ indicates more predictability and high $\mathrm{EQ}$, whereas a low value of $\mathrm{R}^{2}$ indicates low predictability and low EQ.

\section{Descriptive Statistics of FI and Control Variables}

Table 3 shows the descriptive statistics of the dependent variable (FI) and control variables. 
Table 3 Descriptive Statistics of Foreign and Control Variables

\begin{tabular}{|c|c|c|c|c|c|c|c|c|}
\hline Variable & Min & Max & Mean & $\begin{array}{c}\text { Std. } \\
\text { Deviation }\end{array}$ & Min & Max & Mean & $\begin{array}{c}\text { Std. } \\
\text { Deviation }\end{array}$ \\
\hline & \multicolumn{4}{|c|}{$\mathrm{KSA}$} & \multicolumn{4}{|c|}{ QAT } \\
\hline FI & 0.00 & 0.50 & 0.0188 & 0.078 & 0.00 & 0.036 & 0.00083 & 0.005 \\
\hline BIG4 & 0.00 & 4.00 & 0.672 & 0.499 & 0.000 & 1.00 & 0.936 & 0.245 \\
\hline $\mathrm{R}$ & 0.01 & 6.44 & 0.889 & 0.920 & -67.02 & 20.45 & -10.28 & 0.939 \\
\hline $\mathrm{S}$ & 1.14 & 5.17 & 2.865 & 0.712 & 1.84 & 4.55 & 3.25 & 0.629 \\
\hline & \multicolumn{4}{|c|}{ OMN } & \multicolumn{4}{|c|}{ BAH } \\
\hline FI & 0.00 & 0.74 & 0.064 & 0.168 & 0.00 & .100 & .0198 & 0.033 \\
\hline BIG4 & 0.00 & 1.00 & 0.643 & 0.480 & 0.00 & 1.00 & .838 & 0.371 \\
\hline $\mathrm{R}$ & -710.0 & 189 & -8.021 & 262.8 & 0.038 & 1.47 & .369 & 0.327 \\
\hline $\mathrm{S}$ & 0.674 & 3.47 & 1.82 & 0.601 & 1.09 & 3.63 & 2.32 & 0.696 \\
\hline & \multicolumn{4}{|c|}{ KUW } & \multicolumn{4}{|c|}{ UAE } \\
\hline FI & 0.00 & 2.00 & .0409 & 0.784 & 0.00 & 0.20 & 0.0323 & 0.055 \\
\hline BIG4 & 0.00 & 1.00 & .661 & 0.477 & 0.00 & 1.00 & 0.778 & 0.417 \\
\hline $\mathrm{R}$ & 0.00 & 4.74 & 1.325 & 1.261 & 0.04 & 13.84 & 1.33 & 2.305 \\
\hline $\mathrm{S}$ & 1.56 & 3.58 & 2.646 & 0.617 & 1.99 & 4.68 & 3.063 & 0.622 \\
\hline
\end{tabular}

The mean of FI is very low in all GCC countries as it is between 0.00083 (Qatar) and 0.0643 (Oman). The highest mean is in Oman (0.0643), KUW (0.0409), UAE (0.0323), BAH (0.0198), KSA (0.0188) and finally QAT (0.00083). This indicates that FI is very low in GCC, but OMN has the better capital market for FI during the period of the study. Firm sizes (S) have mean values between 1.82 (Oman) and 3.25 (Qatar). With this range, firms have adequate assets to sustain their growth and survival. These results indicate that Qatari firms offer a strong asserts structure than UAE, KSA, KUW, $\mathrm{BAH}$, and the lowest is in OMN. The mean of risk is between 1.33 (UAE) and -10.28 (Qatar), suggesting that risk is high in this sample because of the nature of the sample (non-financial firms) and the situation in the GCC region. The highest mean of risk is in UAE, which is around $133 \%$, then KUW (132.5\%), KSA (88.9\%), BAH (36.9\%), and the lowest mean of risk is in QAT (-10.28), and OMN (-8.021) which means that QAT and OMN are the best of GCC countries for investment. All GCC countries prefer to hire big 4 audit firms as the highest mean is for Qatar, which is around $94 \%$ and the lowest one is for Oman, which is around 64\%. These results indicate that the GCC nonfinancial firms prefer to hire the Big 4 audit firms to audit their financial statements because they strongly believe that Big 4 audit firms offer high audit quality. Accordingly, the descriptive statistics of this research give a good presentation of the data, and we can process the data for analysis.

\section{Measuring and Analysis of EQ-PER and FI}


The required information to calculate the persistence of EQ is the NIBE in the current year and in the previous year. Table 4 shows the mean, SD, and correlation of the variables of persistence.

Table 4 Descriptive Statistics and Measuring of Earnings Persistence

\begin{tabular}{cccccccc}
\hline & \multicolumn{2}{c}{ NBIE } & \multicolumn{2}{c}{ NBIE-1 } & R & P-value & EQ(PER): $\beta$ \\
\hline KSA & Mean & SD & Mean & SD & & & $0.333^{* *}$ \\
\hline OMN & 1.61 & 0.784 & 2.32 & 12.89 & $0.329^{* *}$ & 0.000 & $0.610^{* *}$ \\
\hline QAT & 0.615 & 0.738 & 0.084 & 0.736 & $0.618^{* *}$ & 0.000 & $0.490^{* *}$ \\
\hline BAH & 1.99 & 0.550 & 1.15 & 0.632 & $0.607^{* *}$ & 0.000 & $0.504^{* *}$ \\
\hline KUW & 1.20 & 0.720 & 0.213 & 0.846 & $0.628^{* *}$ & 0.000 & $0.518^{* *}$ \\
\hline UAE & 1.65 & 0.730 & 0.504 & 0.919 & $0.621^{* *}$ & 0.000 & $0.405^{* *}$ \\
\hline
\end{tabular}

Note. $* *$ Correlation is significant at the 0.01 level (2-tailed).

As shown in Table 4, all means of NIBE are positive. The highest mean is for Qatar (1.99), and the lowest is for Oman (0.615). The NIBE and NIBE-1 are positively correlated in all GCC countries at the significant level of 0.000 . The correlation is quite high to conclude that earnings are stable and high. The highest correlation is in Bahrain (0.628) (p-value<0.01), and the lowest one is in KSA (0.329) (p-value<0.01). The criterion which is used to rank the EQ measured by persistence is the value of slopecoefficient $\beta$. The value of $\beta$ in Oman is closer to one than the other countries. Although the values for the other countries are good, the value of $\beta$ in KSA is closer to zero than the other countries. This result means that the earnings of Omani firms (and other countries except for KSA) are more persistent and sustainable. Hence, we expect that the decision usefulness of EQ is high and thus provides valuable financial information to stakeholders, including foreign investors. These results are different from the results of An (2017) which found the value of $\beta$ in Korea very close to zero. Our results align with those of Ahn and Kwon (2010), which found that earnings are highly persistent in Korea due to the high levels of cash flows.

Table 5 shows the regression results of the effect of EQ-PER on FI. 
Table 5 Regression Results between PER and FI

\begin{tabular}{|c|c|c|c|c|c|c|c|c|c|c|c|c|}
\hline \multirow{2}{*}{$\begin{array}{l}\text { Country } \\
\text { Variables }\end{array}$} & \multicolumn{2}{|c|}{ KSA } & \multicolumn{2}{|c|}{ OMN } & \multicolumn{2}{|c|}{ QAT } & \multicolumn{2}{|c|}{ BAH } & \multicolumn{2}{|c|}{ KUW } & \multicolumn{2}{|c|}{ UAE } \\
\hline & B & $\begin{array}{c}\mathrm{t}- \\
\text { value }\end{array}$ & B & $\begin{array}{c}\mathrm{t}- \\
\text { value }\end{array}$ & B & $\begin{array}{c}\mathrm{t}- \\
\text { value }\end{array}$ & B & $\begin{array}{c}\mathrm{t}- \\
\text { value }\end{array}$ & B & $\begin{array}{c}\mathrm{t}- \\
\text { value }\end{array}$ & B & $\begin{array}{c}\mathrm{t}- \\
\text { value }\end{array}$ \\
\hline $\begin{array}{c}\text { EQ } \\
(\mathrm{PER})\end{array}$ & $\begin{array}{l}-0.001 \\
(0.148)\end{array}$ & -1.45 & $\begin{array}{c}0.031 \\
(0.029)\end{array}$ & 2.183 & $\begin{array}{c}0.001 \\
(0.672)\end{array}$ & 0.426 & $\begin{array}{c}0.006 \\
(0.520)\end{array}$ & 0.605 & $\begin{array}{l}-0.297 \\
(0.247)\end{array}$ & $\begin{array}{c}- \\
1.172\end{array}$ & $\begin{array}{c}0.024 \\
(0.190)\end{array}$ & 1.319 \\
\hline Big4 & $\begin{array}{l}-0.013 \\
(0.037)\end{array}$ & -2.06 & $\begin{array}{c}0.042 \\
(0.000)\end{array}$ & 4.112 & -0.404 & 0.130 & $\begin{array}{c}0.08 \\
(0.000)\end{array}$ & 4.756 & $\begin{array}{c}-0.121 \\
(0.608)\end{array}$ & $\begin{array}{c}- \\
0.516\end{array}$ & $\begin{array}{c}0.013 \\
(0.366)\end{array}$ & 0.908 \\
\hline Risk & $\begin{array}{c}0.010 \\
(0.003) \\
\end{array}$ & 2.95 & $\begin{array}{c}0.011 \\
(0.776) \\
\end{array}$ & 0.285 & $\begin{array}{c}7.3 \\
(0.621) \\
\end{array}$ & 0.496 & $\begin{array}{l}-0.032 \\
(0.003) \\
\end{array}$ & $\begin{array}{c}- \\
3.123 \\
\end{array}$ & $\begin{array}{l}-0.011 \\
(0.897) \\
\end{array}$ & $\begin{array}{c}- \\
0.130 \\
\end{array}$ & $\begin{array}{l}-0.003 \\
(0.516) \\
\end{array}$ & $\begin{array}{c}- \\
0.651 \\
\end{array}$ \\
\hline Size & $\begin{array}{c}0.004 \\
(0.334) \\
\end{array}$ & .966 & $\begin{array}{c}0.031 \\
(0.000) \\
\end{array}$ & 3.848 & $\begin{array}{l}-0.004 \\
(0.001) \\
\end{array}$ & $\begin{array}{c}- \\
3.618 \\
\end{array}$ & $\begin{array}{l}-0.022 \\
(0.000) \\
\end{array}$ & $\begin{array}{c}- \\
3.922 \\
\end{array}$ & $\begin{array}{c}0.553 \\
(0.007) \\
\end{array}$ & 2.824 & $\begin{array}{c}0.003 \\
(0.792) \\
\end{array}$ & 0.265 \\
\hline $\begin{array}{c}\mathrm{R} \\
\text { (Model) }\end{array}$ & \multicolumn{2}{|c|}{0.136} & \multicolumn{2}{|c|}{$0.226^{* *}$} & \multicolumn{2}{|c|}{$0.390 * *$} & \multicolumn{2}{|c|}{$0.609 * *$} & \multicolumn{2}{|c|}{$0.417 *$} & \multicolumn{2}{|c|}{0.196} \\
\hline $\mathrm{R}^{2}$ & \multicolumn{2}{|c|}{0.019} & \multicolumn{2}{|c|}{0.051} & \multicolumn{2}{|c|}{0.152} & \multicolumn{2}{|c|}{0.371} & \multicolumn{2}{|c|}{0.174} & \multicolumn{2}{|c|}{0.038} \\
\hline F-value & \multicolumn{2}{|c|}{3.329} & \multicolumn{2}{|c|}{8.605} & \multicolumn{2}{|c|}{4.436} & \multicolumn{2}{|c|}{10.170} & \multicolumn{2}{|c|}{2.577} & \multicolumn{2}{|c|}{1.137} \\
\hline Sig. & \multicolumn{2}{|c|}{0.010} & \multicolumn{2}{|c|}{0.000} & \multicolumn{2}{|c|}{0.006} & \multicolumn{2}{|c|}{0.000} & \multicolumn{2}{|c|}{0.049} & \multicolumn{2}{|c|}{0.343} \\
\hline
\end{tabular}

Note. ${ }^{* *}$ Correlation is significant at the 0.01 level (2-tailed).

*Correlation is significant at the 0.05 level (2-tailed).

Table 5 shows that the regression model in KSA, Oman, Qatar, and Bahrain is significant at 0.01 and Kuwait at 0.05 (but not in UAE). However, EQ-PER has a significantly positive effect on attracting foreign investors only in Oman as the coefficient is 0.031 ( $\mathrm{p}$-value<0.05), and the $\mathrm{R}^{2}$ of EQ-PER explains $5.1 \%$ of the variation in attracting foreign investors. This result indicates that the sustainability of earnings in Oman will attract more foreign investors. $\mathrm{H} 1$ is accepted only in Oman but not in other GCC countries. To provide useful information to foreign investors, the sustainability of earnings appears only with large firms and firms audited by big 4 audit firms as the coefficients (0.031 and 0.042, respectively) are significant at 0.01 .

The result of this study is not in line with that of Ahn and Kwon (2010), which found that Korean investors do not have any reaction to the persistence of earnings. This result is also not in line with that of Wang (2014), which found that a high degree of persistence is not real as the reaction of investors is negative. The result of this measure in Oman is in line with Ben-Nasr et al. (2015), which found that FI is associated with more earnings persistence.

\section{Measuring and Analysis of EQ-P and FI}

The required information to calculate the predictability of earnings is the same as the information on persistence. Table 6 shows the regression of predictability in Equation 1. 
Table 6 Results of Measuring Predictability

\begin{tabular}{c|c|c|c|c|c|c}
\hline Variable & KSA & OMN & QAT & BAH & KUW & UAE \\
\hline $\mathrm{EQ}(\mathrm{P})-\mathrm{R}^{2}$ & $10.8 \%$ & $38.2 \%$ & $36.8 \%$ & $39.4 \%$ & $38.6 \%$ & $21.8 \%$ \\
\hline
\end{tabular}

The criterion used to rank EQ measured by $\mathrm{R}^{2}$ is calculated as in EQ-PER. Generally, the results of Table 6 indicate that $\mathrm{R}^{2}$ is low in all six GCC countries. The first rank is Bahrain as its $\mathrm{R}^{2}$ is the highest one among the other countries (39.4\%) then the second rank is Kuwait (38.6\%), followed by Oman (38.2\%) and then Qatar (36.8\%). The $\mathrm{R}^{2}$ for the other two countries (KSA and UAE) is low, and the lowest one is for KSA $(10.8 \%)$. These results indicate that the predictive value of earnings is more in Bahrain, Kuwait, Oman, and Qatar, but it is low in the KSA and UAE. In general, the predictive value of earnings in GCC countries as measured by $\mathrm{R}^{2}$ is below $50 \%$, which is low. The EQ measured by predictability may not help investors decide about their investment in the future.

The result of this study is inconsistent with Holt (2013), which found that predictability is a good indicator to predict future earnings when the average of $R^{2}$ is around $70 \%$.

Table 7 shows the results of the regression between EQ-P and FI.

Table 7 Results of Regression between P and FI

\begin{tabular}{|c|c|c|c|c|c|c|c|c|c|c|c|c|}
\hline \multirow{2}{*}{$\begin{array}{l}\text { Country } \\
\text { Variablas }\end{array}$} & \multicolumn{2}{|c|}{ KSA } & \multicolumn{2}{|c|}{ OMN } & \multicolumn{2}{|c|}{ QAT } & \multicolumn{2}{|c|}{ BAH } & \multicolumn{2}{|c|}{ KUW } & \multicolumn{2}{|c|}{ UAE } \\
\hline & B & $\begin{array}{c}\mathrm{t}- \\
\text { value }\end{array}$ & B & $\begin{array}{c}\mathrm{t}- \\
\text { value }\end{array}$ & B & $\begin{array}{c}\mathrm{t}- \\
\text { value }\end{array}$ & B & $\begin{array}{c}\mathrm{t}- \\
\text { value }\end{array}$ & B & $\begin{array}{c}\mathrm{t}- \\
\text { value }\end{array}$ & B & $\begin{array}{c}\mathrm{t}- \\
\text { value }\end{array}$ \\
\hline EQ (P) & $\begin{array}{l}-0.045 \\
(0.013) \\
\end{array}$ & -2.481 & $\begin{array}{l}0.052 \\
(0.01) \\
\end{array}$ & 2.58 & $\begin{array}{r}-0.005 \\
(0.157) \\
\end{array}$ & -1.43 & $\begin{array}{c}0.015 \\
(0.208) \\
\end{array}$ & 1.26 & $\begin{array}{l}-1.416 \\
(0.019) \\
\end{array}$ & $2 . \overline{-}$ & $\begin{array}{c}0.044 \\
(0.066) \\
\end{array}$ & 1.856 \\
\hline Big4 & $\begin{array}{l}-0.013 \\
(0.039) \\
\end{array}$ & -2.064 & $\begin{array}{c}0.042 \\
(0.000) \\
\end{array}$ & 4.105 & $\begin{array}{c}0.105 \\
(0.001) \\
\end{array}$ & 1.235 & $\begin{array}{c}0.039 \\
(0.001) \\
\end{array}$ & 3.411 & $\begin{array}{c}0.040 \\
(0.867) \\
\end{array}$ & 0.168 & $\begin{array}{c}0.021 \\
(0.156) \\
\end{array}$ & 1.427 \\
\hline Risk & $\begin{array}{c}0.010 \\
(0.002) \\
\end{array}$ & 3.093 & $\begin{array}{c}0.012 \\
(0.783) \\
\end{array}$ & 0.302 & $\begin{array}{c}0.089 \\
(0.408) \\
\end{array}$ & 0.832 & $\begin{array}{c}0.003 \\
(0.371) \\
\end{array}$ & 0.89 & $\begin{array}{l}-0.026 \\
(0.754) \\
\end{array}$ & $\begin{array}{c}- \\
0.315 \\
\end{array}$ & $\begin{array}{l}-0.003 \\
(0.560) \\
\end{array}$ & $\begin{array}{c}- \\
0.585 \\
\end{array}$ \\
\hline Size & $\begin{array}{c}0.006 \\
(0.148) \\
\end{array}$ & 1.448 & $\begin{array}{l}-0.031 \\
(0.000) \\
\end{array}$ & -3.836 & $\begin{array}{l}-0.004 \\
(0.098) \\
\end{array}$ & -1.68 & $\begin{array}{l}-0.018 \\
(0.019) \\
\end{array}$ & -2.34 & $\begin{array}{c}0.076 \\
(0.001) \\
\end{array}$ & 3.637 & $\begin{array}{c}0.004 \\
(0.662) \\
\end{array}$ & 0.438 \\
\hline $\begin{array}{c}\mathrm{R} \\
\text { (Model) }\end{array}$ & \multicolumn{2}{|c|}{$0.168 * *$} & \multicolumn{2}{|c|}{$0.222 * *$} & \multicolumn{2}{|c|}{0.199} & \multicolumn{2}{|c|}{$0.459 * *$} & \multicolumn{2}{|c|}{$0.492 * *$} & \multicolumn{2}{|c|}{0.229} \\
\hline $\mathrm{R}^{2}$ & \multicolumn{2}{|c|}{0.028} & \multicolumn{2}{|c|}{0.049} & \multicolumn{2}{|c|}{0.040} & \multicolumn{2}{|c|}{0.210} & \multicolumn{2}{|c|}{0.242} & \multicolumn{2}{|c|}{0.052} \\
\hline F-value & \multicolumn{2}{|c|}{5.038} & \multicolumn{2}{|c|}{7.91} & \multicolumn{2}{|c|}{2.04} & \multicolumn{2}{|c|}{8.44} & \multicolumn{2}{|c|}{3.920} & \multicolumn{2}{|c|}{1.573} \\
\hline Sig. & \multicolumn{2}{|c|}{0.001} & \multicolumn{2}{|c|}{0.01} & \multicolumn{2}{|c|}{0.158} & \multicolumn{2}{|c|}{0.001} & \multicolumn{2}{|c|}{0.008} & \multicolumn{2}{|c|}{0.186} \\
\hline
\end{tabular}

Note. **Correlation is significant at the 0.01 level (2-tailed).

*Correlation is significant at the 0.05 level (2-tailed).

Table 7 shows that the model is significant in KSA, Oman, Bahrain, and Kuwait at 0.01 level. As expected, in KSA and Kuwait, the coefficients (-0.045 and -1.416) of EQ are significant but negative ( $\mathrm{p}$-value $<0.05$ ), indicating a negative association between predictability and foreign investors. Investors cannot depend on current 
earnings to predict future earnings. $\mathrm{H} 2$ is accepted only in Oman as the coefficient $(0.052)$ is positive and significant ( $\mathrm{p}$-value $<0.05$ ). Foreign investors tend to decide on their investments based on current earnings when predicting future earnings. This result is in line with that of Lee and Kim (2019).

In Bahrain, Qatar, and UAE, the coefficients (-0.005, 0.015, and 0.044, respectively) are insignificant at the 0.05 level, indicating that the predictability of earnings does not influence foreign investors. The control variables have different effects on foreign investors, confirming the significance of these variables.

\section{Measuring and Analysis of EQ-ERC, EQ-VR, and FI}

The required information to calculate ERC is the NIBE and NIBE/P, as shown in Table 8 which lists the mean, SD, $\beta$ of the variables of EQ-VR.

Table 8 Descriptive Statistics and Measuring the ERC and Value Relevance

\begin{tabular}{|c|c|c|c|c|c|c|c|c|c|c|c|c|}
\hline Country & \multicolumn{2}{|c|}{ KSA } & \multicolumn{2}{|c|}{$\mathrm{OMN}$} & \multicolumn{2}{|c|}{ QAT } & \multicolumn{2}{|c|}{$\mathrm{BAH}$} & \multicolumn{2}{|c|}{ KUW } & \multicolumn{2}{|c|}{ UAE } \\
\hline Variable & Mean & $\mathrm{SD}$ & Mean & SD & Mean & SD & Mean & $\mathrm{SD}$ & Mean & SD & Mean & SD \\
\hline NIBE & 1.61 & 0.784 & 0.615 & 0.738 & 1.99 & 0.550 & 1.20 & 0.720 & 1.12 & 0.729 & 1.65 & 0.643 \\
\hline Return (Ret) & 1.35 & 0.495 & 1.29 & 0.660 & 1.32 & 0.531 & 1.08 & 0.421 & 1.18 & 0.549 & 1.43 & 0.575 \\
\hline $\mathrm{P}$ & 0.96 & 0.288 & 0.072 & 0.465 & 0.827 & 0.544 & 0.035 & 0.247 & 1.51 & 0.370 & 0.228 & 0.826 \\
\hline NIBE/P & 0.655 & 0.739 & 0.627 & 0.689 & 0.827 & 0.544 & 1.40 & 0.604 & 1.25 & 0.611 & 1.90 & 0.626 \\
\hline Correlation & \multicolumn{2}{|c|}{0.019} & \multicolumn{2}{|c|}{$0.288 * *$} & \multicolumn{2}{|c|}{$0.223^{*}$} & \multicolumn{2}{|c|}{0.078} & \multicolumn{2}{|c|}{0.110} & \multicolumn{2}{|c|}{$0.224 *$} \\
\hline $\begin{array}{c}\text { EQ (ERC)- } \\
\beta \\
\end{array}$ & \multicolumn{2}{|c|}{0.058} & \multicolumn{2}{|c|}{$0.268 * *$} & \multicolumn{2}{|c|}{-0.228} & \multicolumn{2}{|c|}{-0.064} & \multicolumn{2}{|c|}{-0.091} & \multicolumn{2}{|c|}{$-0.222 *$} \\
\hline
\end{tabular}

Note. $* *$ Correlation is significant at the 0.01 level (2-tailed).

*Correlation is significant at the 0.05 level (2-tailed).

The means of Ret are positive. The highest is for UAE (1.43), and the lowest is for Bahrain (1.08). Most GCC firms have positive earnings. The stock price as measured by closing price is more than the par value in all GCC countries. The slope of coefficient $\beta$ is very low in all six GCC countries, which means that the decision usefulness of EQ is low. The correlation between the Ret and NIBE/P supports this conclusion as it is very low in all GCC countries.

The results of this study are against the results of Perotti and Wagenhofer (2014), Chandrapala (2013), and An (2017), which indicate that value relevance of earnings, stock price, and returns of listed firms should be improved. The results are in line with Callao et al. (2016) study, which found that the value relevance of earnings is low.

Table 9 shows the results of the relationship between value relevance (ERC) and FI. 
Table 9 Regression Results between VR-ERC and FI

\begin{tabular}{|c|c|c|c|c|c|c|c|c|c|c|c|c|}
\hline \multirow{2}{*}{ Variables } & \multicolumn{2}{|c|}{$\mathrm{KSA}$} & \multicolumn{2}{|c|}{ OMN } & \multicolumn{2}{|c|}{ QAT } & \multicolumn{2}{|c|}{ BAH } & \multicolumn{2}{|c|}{ KUW } & \multicolumn{2}{|c|}{ UAE } \\
\hline & B & $\begin{array}{c}\mathrm{t}- \\
\text { value }\end{array}$ & B & $\begin{array}{c}\mathrm{t}- \\
\text { value }\end{array}$ & B & t-value & B & $\begin{array}{c}\mathrm{t}- \\
\text { value }\end{array}$ & B & t-value & B & $\begin{array}{c}\mathrm{t}- \\
\text { value }\end{array}$ \\
\hline $\begin{array}{l}\mathrm{EQ}(\mathrm{ERC}) \& \\
\text { sig. }\end{array}$ & $\begin{array}{l}-0.004 \\
(0.000) \\
\end{array}$ & -3.629 & $\begin{array}{c}0.100 \\
(0.010) \\
\end{array}$ & 2.601 & $\begin{array}{c}-0.050 \\
(0.960) \\
\end{array}$ & -0.007 & $\begin{array}{c}-0.041 \\
(0.729) \\
\end{array}$ & -0.348 & $\begin{array}{c}0.056 \\
(0.019) \\
\end{array}$ & 2.420 & $\begin{array}{l}-0.075 \\
(0.534) \\
\end{array}$ & -0.623 \\
\hline Big4 & $\begin{array}{c}-0.017 \\
(0.006)\end{array}$ & -2.730 & $\begin{array}{c}0.043 \\
(0.000)\end{array}$ & 4.250 & $\begin{array}{c}0.521 \\
(0.000)\end{array}$ & 2.276 & $\begin{array}{r}0.047 \\
(0.000)\end{array}$ & 4.755 & $\begin{array}{c}0.014 \\
(0.952)\end{array}$ & 0.061 & $\begin{array}{c}0.013 \\
(0.368)\end{array}$ & 0.904 \\
\hline Risk & $\begin{array}{c}0.009 \\
(0.005)\end{array}$ & 2.807 & $\begin{array}{c}0.015 \\
(0.689)\end{array}$ & 0.400 & $\begin{array}{c}0.055 \\
(0.662)\end{array}$ & 0.438 & $\begin{array}{c}-0.032 \\
(0.003)\end{array}$ & -3.028 & $\begin{array}{c}0.007 \\
(0.930)\end{array}$ & 0.088 & $\begin{array}{c}-0.004 \\
(0.465)\end{array}$ & -0.732 \\
\hline Size & $\begin{array}{c}0.007 \\
(0.106) \\
\end{array}$ & 1.618 & $\begin{array}{c}-.031 \\
(0.000) \\
\end{array}$ & -3.798 & $\begin{array}{c}-0.391 \\
(0.001) \\
\end{array}$ & -3.337 & $\begin{array}{c}-.041 \\
(0.001) \\
\end{array}$ & -3.438 & $\begin{array}{c}0.596 \\
(0.002) \\
\end{array}$ & 3.234 & $\begin{array}{c}0.003 \\
(0.819) \\
\end{array}$ & 0.230 \\
\hline R (Model) & \multicolumn{2}{|c|}{$0.188^{* *}$} & \multicolumn{2}{|c|}{$0.233^{* *}$} & \multicolumn{2}{|c|}{$0.380^{* *}$} & \multicolumn{2}{|c|}{$0.609 * *$} & \multicolumn{2}{|c|}{$0.491 * *$} & \multicolumn{2}{|c|}{0.164} \\
\hline $\mathrm{R}^{2}$ & \multicolumn{2}{|c|}{0.035} & \multicolumn{2}{|c|}{0.054} & \multicolumn{2}{|c|}{0.150} & \multicolumn{2}{|c|}{0.370} & \multicolumn{2}{|c|}{0.241} & \multicolumn{2}{|c|}{0.027} \\
\hline F-value & \multicolumn{2}{|c|}{6.417} & \multicolumn{2}{|c|}{9.128} & \multicolumn{2}{|c|}{4.366} & \multicolumn{2}{|c|}{10.111} & \multicolumn{2}{|c|}{3.898} & \multicolumn{2}{|c|}{0.791} \\
\hline Sig. & \multicolumn{2}{|c|}{0.000} & \multicolumn{2}{|c|}{0.000} & \multicolumn{2}{|c|}{0.007} & \multicolumn{2}{|c|}{0.000} & \multicolumn{2}{|c|}{0.008} & \multicolumn{2}{|c|}{0.533} \\
\hline
\end{tabular}

Note. $* *$ Correlation is significant at the 0.01 level (2-tailed).

*Correlation is significant at the 0.05 level (2-tailed).

Table 9 shows that the model is significant in all GCC countries except for UAE at 0.01 . H3a is accepted in Oman and Kuwait as the value relevance (ERC) significantly affects attracting foreign investors in Oman and Kuwait at 0.05. In Oman, the coefficient is 0.100 ( $\mathrm{p}$-value $<0.05$ ), and the $\mathrm{R}^{2}$ of ERC explains $5.4 \%$ of the variation of attracting foreign investors. In Kuwait, the coefficient is equal to 0.056 (pvalue $<0.05$ ), and the $\mathrm{R}^{2}$ of ERC explains $24.1 \%$ of the variation in attracting foreign investors. In KSA, the value relevance (ERC) has a significantly negative effect on attracting foreign investors as the coefficient is -0.004 ( $\mathrm{p}$-value $<0.01$ ). The $\mathrm{R}^{2}$ of ERC explains $3.5 \%$ of the variation of attracting foreign investors. The result indicates that any improvement in the informativeness of financial reporting measured by ERC will attract more foreign investors in Oman and Kuwait. This result is consistent with Jiang and Kim (2004) which found that foreign investors prefer to invest in an environment with high informational advantages and low information asymmetry. The result is supported by Choi et al. (2013) which pointed out that the pressure for increased informational content and increased value relevance of financial reporting will attract more foreign investors. In the case of KSA, foreign investors seem to have doubts about the relationship between ERC and the informativeness of financial reporting of listed firms, although the value of ERC is good in this country.

The required data to calculate $\mathrm{R}^{2}$ of the second measure of value relevance are EPS, the book value of shares, and share price. Table 10 shows the results of this measure. 
Table 10 Descriptive Statistics and Measuring of Value Relevance (R2)

\begin{tabular}{|c|c|c|c|c|c|c|c|c|c|c|c|c|}
\hline \multirow{2}{*}{ Variable } & \multicolumn{2}{|c|}{ KSA } & \multicolumn{2}{|c|}{ OMN } & \multicolumn{2}{|c|}{ QAT } & \multicolumn{2}{|c|}{ BAH } & \multicolumn{2}{|c|}{ KUW } & \multicolumn{2}{|c|}{ UAE } \\
\hline & Mean & SD & Mean & SD & Mean & SD & Mean & SD & Mean & SD & Mean & SD \\
\hline EPS & 0.438 & 0.746 & 0.155 & 0.440 & 1.54 & 1.13 & 0.108 & 0.076 & 0.073 & 0.071 & 0.047 & 0.159 \\
\hline BV & 3.76 & 2.57 & 1.49 & 2.76 & 10.12 & 8.12 & 0.943 & 0.369 & 0.742 & 0.425 & 0.702 & 0.687 \\
\hline $\mathrm{P}$ & 0.96 & 0.288 & 0.072 & 0.465 & 0.827 & 0.544 & 0.035 & 0.247 & 1.51 & 0.370 & 0.228 & 0.826 \\
\hline $\begin{array}{c}\text { Correlation } \\
(\text { EPS\&P) }\end{array}$ & \multicolumn{2}{|c|}{$0.357 * *$} & \multicolumn{2}{|c|}{$0.603 * *$} & \multicolumn{2}{|c|}{$0.817 * *$} & \multicolumn{2}{|c|}{$0.841 * *$} & \multicolumn{2}{|c|}{$0.840 * *$} & \multicolumn{2}{|c|}{$0.283 * *$} \\
\hline $\begin{array}{c}\text { Correlation } \\
(\mathrm{BV} \& \mathrm{P})\end{array}$ & \multicolumn{2}{|c|}{$0.387 * *$} & \multicolumn{2}{|c|}{$0.728 * *$} & \multicolumn{2}{|c|}{$0.614 * *$} & \multicolumn{2}{|c|}{$0.453 * *$} & \multicolumn{2}{|c|}{$0.582 * *$} & \multicolumn{2}{|c|}{$0.514 * *$} \\
\hline $\begin{array}{c}\text { Correlation } \\
\text { (Model) }\end{array}$ & \multicolumn{2}{|c|}{$0.467 * *$} & \multicolumn{2}{|c|}{$0.733 * *$} & \multicolumn{2}{|c|}{$0.819 * *$} & \multicolumn{2}{|c|}{$0.843 * *$} & \multicolumn{2}{|c|}{$0.848 * *$} & \multicolumn{2}{|c|}{$0.524 * *$} \\
\hline $\mathrm{EQ}(\mathrm{VR})-\mathrm{R}^{2}$ & \multicolumn{2}{|c|}{0.219} & \multicolumn{2}{|c|}{0.537} & \multicolumn{2}{|c|}{0.671} & \multicolumn{2}{|c|}{0.711} & \multicolumn{2}{|c|}{0.720} & \multicolumn{2}{|c|}{0.274} \\
\hline $\begin{array}{l}\text { Coefficient } \\
\text { (EPS) }\end{array}$ & \multicolumn{2}{|c|}{$2.982 * *$} & \multicolumn{2}{|c|}{$0.908^{*}$} & \multicolumn{2}{|c|}{$10.12^{* *}$} & \multicolumn{2}{|c|}{$6.676^{* *}$} & \multicolumn{2}{|c|}{$10.095^{* *}$} & \multicolumn{2}{|c|}{0.634} \\
\hline $\begin{array}{l}\text { Coefficient } \\
\text { (BV) }\end{array}$ & 1.04 & $5 * *$ & 0.7 & $9 * *$ & & & 0.1 & & 0.3 & & 0.65 & \\
\hline
\end{tabular}

Note. ${ }^{* *}$ Correlation is significant at the 0.01 level (2-tailed).

*Correlation is significant at the 0.05 level (2-tailed).

Table 10 shows that the mean value of share price $(\mathrm{P})$, book values of share (BV), and earnings per share (EPS) for the GCC firms have positive values. All positive values of the three variables suggest that most GCC firms are financially stable. The highest mean is Qatar (1.54), and the lowest is UAE (0.047). The $\mathrm{R}^{2}$ in Kuwait (72\%) is the highest among the GCC countries, and the lowest is in KSA (21.9\%). The second rank is for Bahrain (71.1\%), then Qatar (67.1\%), followed by Oman (53.7\%) and UAE $(27.4 \%)$. These results indicate that the explanatory powers of accounting data of book values and earnings per share jointly explain $72 \%$ of the share price variation in Kuwait, whereas the explanatory powers of accounting data of book values and earnings per share jointly explain only $21.9 \%$ in KSA.

The model in all GCC countries is significant at 0.000 , and the associations between EPS, book value, and share price are positively significant at 0.000 . This result implies that the share price of GCC firms is significantly reflected by EPS and book values ranging from high in Kuwait, Bahrain, and Qatar to low in Oman, UAE, and KSA. The correlations among independent variables (EPS and BV) in all GCC countries are smaller than 0.8 , but multicollinearity is not a serious issue in regression models (Hair et al., 2006). The results of measuring EQ-VR are in line with Ragab and Omran (2006), which found a positive relationship between earnings and share price. Table 11 shows the results of the relationship between EQ-VR and FI. 
Table 11 Regression Results between VR and FI

\begin{tabular}{|c|c|c|c|c|c|c|c|c|c|c|c|c|}
\hline \multirow{2}{*}{$\begin{array}{l}\text { Gountry } \\
\text { Variables }\end{array}$} & \multicolumn{2}{|c|}{ KSA } & \multicolumn{2}{|c|}{ OMN } & \multicolumn{2}{|c|}{ QAT } & \multicolumn{2}{|c|}{ BAH } & \multicolumn{2}{|c|}{ KUW } & \multicolumn{2}{|c|}{ UAE } \\
\hline & B & t-value & B & t-value & B & t-value & B & t-value & B & t-value & B & t-value \\
\hline $\begin{array}{c}\text { EQ (VR) } \\
\& \text { sig. }\end{array}$ & $\begin{array}{c}-0.382 \\
(0.002) \\
\end{array}$ & -3.129 & $\begin{array}{l}-0.209 \\
(0.002) \\
\end{array}$ & -3.087 & $\begin{array}{c}0.005 \\
(0.163) \\
\end{array}$ & 1.409 & $\begin{array}{c}0.071 \\
(0.319) \\
\end{array}$ & 1.003 & $\begin{array}{r}18.388 \\
(0.001) \\
\end{array}$ & 3.364 & $\begin{array}{c}-0.056 \\
(0.012) \\
\end{array}$ & -2.550 \\
\hline Big4 & $\begin{array}{c}-0.014 \\
(0.023) \\
\end{array}$ & -2.276 & $\begin{array}{c}0.044 \\
(0.000) \\
\end{array}$ & 4.362 & $\begin{array}{c}0.203 \\
(0.000) \\
\end{array}$ & 3.751 & $\begin{array}{c}0.049 \\
(0.000) \\
\end{array}$ & 4.939 & $\begin{array}{c}-0.133 \\
(0.528) \\
\end{array}$ & -0.636 & $\begin{array}{c}0.023 \\
(0.105) \\
\end{array}$ & 1.634 \\
\hline Risk & $\begin{array}{c}0.007 \\
(0.042)\end{array}$ & 2.037 & $\begin{array}{c}0.010 \\
(0.699)\end{array}$ & 0.386 & $\begin{array}{c}0.035 \\
(0.746)\end{array}$ & 0.326 & $\begin{array}{l}-0.029 \\
(0.015)\end{array}$ & -2.497 & $\begin{array}{l}-0.103 \\
(0.226)\end{array}$ & $\begin{array}{c}- \\
1.226\end{array}$ & $\begin{array}{c}-0.006 \\
(0.203)\end{array}$ & -1.281 \\
\hline Size & $\begin{array}{c}0.008 \\
(0.074) \\
\end{array}$ & 1.787 & $\begin{array}{l}-0.029 \\
(0.000)\end{array}$ & -3.591 & $\begin{array}{l}-0.015 \\
(0.000)\end{array}$ & -3.896 & $\begin{array}{l}-0.024 \\
(0.000) \\
\end{array}$ & -3.978 & $\begin{array}{c}0.280 \\
(0.126) \\
\end{array}$ & 1.555 & $\begin{array}{c}0.012 \\
(0.190) \\
\end{array}$ & 1.318 \\
\hline $\begin{array}{c}\mathrm{R} \\
\text { (Model) }\end{array}$ & \multicolumn{2}{|c|}{$0.175^{* *}$} & \multicolumn{2}{|c|}{$0.241 * *$} & \multicolumn{2}{|c|}{$0.415 * *$} & \multicolumn{2}{|c|}{$0.614 * *$} & \multicolumn{2}{|c|}{$0.557 * *$} & \multicolumn{2}{|c|}{0.278} \\
\hline $\mathrm{R}^{2}$ & \multicolumn{2}{|c|}{0.031} & \multicolumn{2}{|c|}{0.058} & \multicolumn{2}{|c|}{0.173} & \multicolumn{2}{|c|}{0.378} & \multicolumn{2}{|c|}{0.310} & \multicolumn{2}{|c|}{0.076} \\
\hline F-value & \multicolumn{2}{|c|}{5.557} & \multicolumn{2}{|c|}{9.850} & \multicolumn{2}{|c|}{5.144} & \multicolumn{2}{|c|}{10.461} & \multicolumn{2}{|c|}{5.505} & \multicolumn{2}{|c|}{2.357} \\
\hline Sig. & \multicolumn{2}{|c|}{0.000} & \multicolumn{2}{|c|}{0.000} & \multicolumn{2}{|c|}{0.003} & \multicolumn{2}{|c|}{0.000} & \multicolumn{2}{|c|}{0.001} & \multicolumn{2}{|c|}{0.058} \\
\hline
\end{tabular}

Note. ${ }^{* *}$ Correlation is significant at the 0.01 level (2-tailed).

*Correlation is significant at the 0.05 level (2-tailed).

Table 11 shows that the model is significant in KSA, Oman, and Bahrain at 0.000 level of significance and in Qatar and Kuwait at 0.01 level of significance, but it is insignificant in UAE at 0.01 and 0.05 . In KSA, the association between EQ-VR and FI is significantly negative as the coefficient is -0.382 (p-value $<0.01$ ) and the $t$-value is 3.129. In Oman, EQ-VR is associated significantly negatively with FI as the coefficient is -2.209 (p- value $<0.01$ ), and the $\mathrm{t}$-value is -3.087 . In UAE, the association between EQ-VR and FI is significantly negative as the coefficient is -0.056 (p-value $<0.05$ ) and the $t-v a l u e$ is -2.550 . These results reflect that foreign investors are concerned about the book value and earnings per share in these countries. The investors are not sure whether the increasing book value and EPS is a good thing or not. These results are matched with the lower explanatory power of earnings in these three countries as they ranked as the last three among the GCC countries.

$\mathrm{H} 3 \mathrm{~b}$ is accepted only in Kuwait as value relevance has a significant positive association with FI, making the accounting information of earnings and book value relevant, significant, and faithfully presented for investor decision-making. This result is in line with Mirza et al. (2019), which found that the accounting information of earnings and book value (and cash flow) is relevant for investors in the Malaysian capital market as the information significantly and positively explains the variation in the share price.

In Qatar and Bahrain, no statistically significant association is noted between EQVR and FI. The coefficient is 0.005, (p-value>0.05) and the t-value is 1.409 in Qatar; 0.071 ( $\mathrm{p}$ - value $>0.05$ ) and 1.003 in Bahrain. This result implies that the accounting information of earnings and book value are irrelevant and insignificant for the decision- 
making purposes of foreign investors. The result is in line with Kadri et al. (2009), which pointed out that earnings are irrelevant in the Malaysian capital market.

To a large extent, the results of the two measures of value relevance are the same in KSA and Kuwait, which means that the two EQ measures are consistent in their effect on attracting foreign investors. In Oman and UAE, the study finds different results as there is a positive association between ERC and FI and no effect in UAE, whereas there is a negative association between EQ-VR and FI in both countries. However, foreign investors should be careful when using value relevance to decide about their investments in Oman, especially for the second measure, as increasing earnings and book value may not reflect the higher share price. The control variables have different effects on foreign investors, confirming the significance of these variables.

\section{Measuring and Analysis of EQ-ESI and FI}

The required information to calculate EQ-ESI is SE, CMS, TD, and TS. Table 12 shows all the required variables.

Table 12 Descriptive Statistics and Measuring of Earnings Surprise Indicator

\begin{tabular}{|c|c|c|c|c|c|c|c|c|c|c|c|c|}
\hline \multirow{2}{*}{$\begin{array}{l}\text { Country } \\
\text { Variable }\end{array}$} & \multicolumn{2}{|c|}{ KSA } & \multicolumn{2}{|c|}{ OMN } & \multicolumn{2}{|c|}{ QAT } & \multicolumn{2}{|c|}{ BAH } & \multicolumn{2}{|c|}{ KUW } & \multicolumn{2}{|c|}{ UAE } \\
\hline & Mean & SD & Mean & SD & Mean & SD & Mean & SD & Mean & SD & Mean & SD \\
\hline SE & 2.56 & 0.643 & 1.44 & 0.630 & 2.88 & 0.549 & 2.14 & 0.649 & 2.19 & 0.517 & 2.72 & 0.533 \\
\hline CMS & 1.51 & 0.845 & 0.243 & 0.945 & 2.20 & 0.740 & 1.23 & 0.841 & 1.114 & 0.600 & 1.79 & 0.861 \\
\hline TD & 2.19 & 1.03 & 1.08 & 0.773 & 2.62 & 0.924 & 1.75 & 0.744 & 2.09 & 0.797 & 2.22 & 0.989 \\
\hline TS & 2.43 & 0.743 & 1.50 & 0.768 & 2.64 & 0.659 & 2.07 & 0.753 & 1.99 & 0.451 & 2.53 & 0.672 \\
\hline $\begin{array}{c}\text { EQ } \\
\text { (ESI) }\end{array}$ & \multicolumn{2}{|c|}{1.33} & \multicolumn{2}{|c|}{1.52} & \multicolumn{2}{|c|}{1.25} & \multicolumn{2}{|c|}{1.28} & \multicolumn{2}{|c|}{1.59} & \multicolumn{2}{|c|}{1.24} \\
\hline
\end{tabular}

Table 12 shows that the highest SE, TD, CMS, and TS among all countries are in Qatar with 2.88, 2.62, 2.22, and 2.64, respectively, whereas the lowest means of these variables are in Oman with 1.44, 1.08, 0.243, and 1.5. The ESI in all countries is more than one, which means that the net operating assets are more than total sales and that the net assets are overstated. This proxy is consistent with the assumption that overstated net assets are less efficient at generating a given level of sales (Barton \& Simko, 2002). In addition, ESI is positive in all GCC countries, which means that the actual results of the firms are higher than the expectation of the analysts, which may be questionable news for the investors. The smaller index of ESI is for UAE. The indices of ESI for the other countries are relatively equal except for Kuwait (1.59) which is the highest one among the GCC countries. Accordingly, the EQ of firms in UAE, Qatar, Bahrain, and KSA is higher than in Kuwait and Oman. 
According to Barton and Simko (2002), the correlation between ESI and net operating assets should be negative as the probability of reporting 'larger positive or smaller negative earnings surprises' decreases with the extent to which net operating assets are already overstated on the balance sheet. We tested this hypothesis and found that the Spearman rank correlation is positive and significant in all GCC countries except for Bahrain as the Spearman rank correlation is negative but insignificant at 0.01 and 0.05. In UAE, Oman, and KSA, the Spearman rank correlation is 0.148, 0.143, and 0.296, respectively, whereas Qatar's Spearman rank correlation is 0.553 . The highest spearman rank correlation is in Kuwait (0.789).

These results are against the hypothesis of Barton and Simko (2002), which indicates that the net assets are overstated, or there is a level of earnings management in the preparation of financial statements. Table 13 shows the results of the relationship between EQ-ESI and FI.

Table 13 Regression Results between ESI and FI

\begin{tabular}{|c|c|c|c|c|c|c|c|c|c|c|c|c|}
\hline \multirow{2}{*}{ Country } & \multicolumn{2}{|c|}{ KSA } & \multicolumn{2}{|c|}{ OMN } & \multicolumn{2}{|c|}{ QAT } & \multicolumn{2}{|c|}{ BAH } & \multicolumn{2}{|c|}{ KUW } & \multicolumn{2}{|c|}{ UAE } \\
\hline & B & t-value & B & t-value & B & t-value & B & t-value & B & $\mathrm{t}$-value & B & $\mathrm{t}$-value \\
\hline $\begin{array}{c}\text { EQ (ESI) } \\
\& \text { sig. }\end{array}$ & $\begin{array}{c}0.012 \\
(0.951)\end{array}$ & -0.062 & $\begin{array}{c}-0.017 \\
(0.884)\end{array}$ & -0.147 & $\begin{array}{l}-0.001 \\
(0.996)\end{array}$ & -0.005 & $\begin{array}{c}0.003 \\
(0.567)\end{array}$ & 0.575 & $\begin{array}{c}0.061 \\
(0.068)\end{array}$ & 1.868 & $\begin{array}{l}-0.020 \\
(0.831)\end{array}$ & -0.214 \\
\hline Big4 & $\begin{array}{c}-0.013 \\
(0.039)\end{array}$ & -2.073 & $\begin{array}{c}0.042 \\
(0.000)\end{array}$ & 4.073 & $\begin{array}{c}0.302 \\
(0.000)\end{array}$ & 3.075 & $\begin{array}{c}0.055 \\
(0.002)\end{array}$ & 3.149 & $\begin{array}{l}-0.539 \\
(0.072)\end{array}$ & -1.841 & $\begin{array}{c}0.012 \\
(0.402)\end{array}$ & 0.842 \\
\hline Risk & $\begin{array}{c}0.009 \\
(0.005)\end{array}$ & 2.832 & $\begin{array}{c}0.013 \\
(0.728)\end{array}$ & 0.348 & $\begin{array}{c}0.051 \\
(0.758)\end{array}$ & 0.309 & $\begin{array}{c}-0.032 \\
(0.003)\end{array}$ & -3.097 & $\begin{array}{c}-0.006 \\
(0.948)\end{array}$ & -0.066 & $\begin{array}{l}-0.004 \\
(0.418)\end{array}$ & -0.813 \\
\hline Size & $\begin{array}{c}0.004 \\
(0.388) \\
\end{array}$ & 0.864 & $\begin{array}{l}-0.030 \\
(0.000) \\
\end{array}$ & -3.725 & $\begin{array}{c}-0.004 \\
(0.001) \\
\end{array}$ & -3.593 & $\begin{array}{c}-0.021 \\
(0.000) \\
\end{array}$ & -4.054 & $\begin{array}{c}0.042 \\
(0.888) \\
\end{array}$ & 0.142 & $\begin{array}{c}0.007 \\
(0.433) \\
\end{array}$ & 0.787 \\
\hline R (Model) & \multicolumn{2}{|c|}{$0.131^{*}$} & \multicolumn{2}{|c|}{$0.210^{* *}$} & \multicolumn{2}{|c|}{0.388} & \multicolumn{2}{|c|}{$0.609^{* *}$} & \multicolumn{2}{|c|}{0.445} & \multicolumn{2}{|c|}{0.155} \\
\hline $\mathrm{R} 2$ & \multicolumn{2}{|c|}{0.017} & \multicolumn{2}{|c|}{0.044} & \multicolumn{2}{|c|}{0.150} & \multicolumn{2}{|c|}{0.371} & \multicolumn{2}{|c|}{0.207} & \multicolumn{2}{|c|}{0.024} \\
\hline F-value & \multicolumn{2}{|c|}{3.068} & \multicolumn{2}{|c|}{7.364} & \multicolumn{2}{|c|}{4.365} & \multicolumn{2}{|c|}{10.194} & \multicolumn{2}{|c|}{3.201} & \multicolumn{2}{|c|}{0.703} \\
\hline Sig. & \multicolumn{2}{|c|}{0.016} & \multicolumn{2}{|c|}{0.000} & \multicolumn{2}{|c|}{0.007} & \multicolumn{2}{|c|}{0.000} & \multicolumn{2}{|c|}{0.051} & \multicolumn{2}{|c|}{0.591} \\
\hline
\end{tabular}

Note. $* *$ Correlation is significant at the 0.01 level (2-tailed).

*Correlation is significant at the 0.05 level (2-tailed).

Table 13 shows that the model of EQ-ESI and FI is significant in KSA, Oman, Qatar, and Bahrain at both 0.05 and 0.01 levels, but it is insignificant in Kuwait and UAE. Again, the significance of the model is because the control variables, as the coefficients of ESI, are insignificant among all GCC countries. H4 is rejected as the result of this model is supported by the higher value of ESI. Foreign investors prefer to use the forecasting provided by analysts when they want to invest their money for the first time. The higher ESI may have a negative effect on the perception of investors about firms. Therefore, with less knowledge about the new capital market, foreign investors believe that the managers use 'meeting or beating analysts' earnings forecasts' as an incentive to manage the earnings and avoid negative earnings surprises. The result of this indicator is in line with Sen (2009), which found that ESI is not a key factor used 
by sophisticated institutional investors. The control variables have different effects on foreign investors, confirming the significance of these variables.

\section{Measuring and Analysis of EQ-AQ and FI}

The required information to calculate the earnings accrual is the operating cash flow in the current year, the previous year, and the future year. Table 14 shows the mean, $\mathrm{SD}$, and correlation of the variables of accruals.

Table 14 Descriptive Statistics and Measuring of Accrual Quality

\begin{tabular}{|c|c|c|c|c|c|c|c|c|c|c|c|c|}
\hline \multirow{2}{*}{ Variable } & \multicolumn{2}{|c|}{ KSA } & \multicolumn{2}{|c|}{ OMN } & \multicolumn{2}{|c|}{ QAT } & \multicolumn{2}{|c|}{ BAH } & \multicolumn{2}{|c|}{ KWU } & \multicolumn{2}{|c|}{ UAE } \\
\hline & Mean & SD & Mean & SD & Mean & SD & Mean & SD & Mean & SD & Mean & SD \\
\hline $\mathrm{CFO}$ & 1.77 & 0.843 & 0.733 & 0.790 & 2.13 & 0.626 & 1.30 & 0.898 & 1.37 & 0.643 & 1.87 & 0.757 \\
\hline CFO-1 & 1.39 & 0.845 & 0.433 & 0.828 & 1.69 & 0.675 & 0.721 & 0.794 & 1.03 & 0.776 & 1.47 & 0.776 \\
\hline $\mathrm{CFO}+1$ & 2.08 & 0.830 & 1.028 & 0.785 & 2.44 & 0.591 & 1.58 & 0.888 & 1.69 & 0.661 & 2.17 & 0.732 \\
\hline VWC & 1.41 & 0.850 & 0.387 & 0.703 & 1.71 & 0.761 & 0.882 & 0.723 & 1.14 & 0.677 & 1.62 & 0.747 \\
\hline $\begin{array}{c}\text { Correlation } \\
\text { (VWC and } \\
\text { CFO) }\end{array}$ & \multicolumn{2}{|c|}{$0.644 * *$} & \multicolumn{2}{|c|}{$0.597 * *$} & \multicolumn{2}{|c|}{$0.583 * *$} & \multicolumn{2}{|c|}{$0.814^{* *}$} & \multicolumn{2}{|c|}{$0.637 * *$} & \multicolumn{2}{|c|}{$0.581 * *$} \\
\hline $\begin{array}{c}\text { Correlation } \\
\text { (VWC and } \\
\text { CFO-1) }\end{array}$ & \multicolumn{2}{|c|}{$0.716^{* *}$} & \multicolumn{2}{|c|}{$0.545^{* *}$} & \multicolumn{2}{|c|}{$0.536^{* *}$} & \multicolumn{2}{|c|}{$0.686^{* *}$} & \multicolumn{2}{|c|}{$0.632 * *$} & \multicolumn{2}{|c|}{$0.422 * *$} \\
\hline $\begin{array}{c}\text { Correlation } \\
\text { (VWC and } \\
\text { CFO+1) }\end{array}$ & \multicolumn{2}{|c|}{$0.683 * *$} & \multicolumn{2}{|c|}{$0.556^{* *}$} & \multicolumn{2}{|c|}{$0.692 * *$} & \multicolumn{2}{|c|}{$0.843^{* *}$} & \multicolumn{2}{|c|}{$0.762 * *$} & \multicolumn{2}{|c|}{$0.558^{* *}$} \\
\hline P-value & \multicolumn{2}{|c|}{0.000} & \multicolumn{2}{|c|}{0.000} & \multicolumn{2}{|c|}{0.000} & \multicolumn{2}{|c|}{0.000} & \multicolumn{2}{|c|}{0.000} & \multicolumn{2}{|c|}{0.000} \\
\hline $\begin{array}{c}\text { EQ(VWC)- } \\
\text { Residual }\end{array}$ & \multicolumn{2}{|c|}{63.866} & \multicolumn{2}{|c|}{48.685} & \multicolumn{2}{|c|}{8.385} & \multicolumn{2}{|c|}{2.549} & \multicolumn{2}{|c|}{3.760} & 16.55 & \\
\hline SD of Residual & 0.57 & & 0.50 & & 0.50 & & 0.34 & & 0.45 & & 0.55 & \\
\hline R-Square & 56. & & 46. & & 59. & & & & & & & \\
\hline
\end{tabular}

Note. ${ }^{* *}$ Correlation is significant at the 0.01 level (2-tailed).

The mean of operating cash flow is more than the mean of NIBE in all GCC countries, but the difference between them is small. There is also a positive and significant correlation between accruals and current, past, and future operating cash flow in all six GCC countries. The result of the correlation between accruals and past and future CFO is in alignment with the argument of Dechow and Dichev (2002), but it is inconsistent with respect to the correlation between accruals and current CFO. However, the most important point in this theory is the relationship between accruals and the future operating cash flow, as suggested by Dechow and Dichev (2002), which defined good EQ as a good relation between accruals and future operating cash flow.

The results of EQ-AQ) shows that the less magnitude of residual or error estimation is found in Bahrain (2.549) with less SD (0.348), and the highest magnitude of residual or error estimation is found in KSA (63.866) with high SD (0.577). The $\mathrm{R}^{2}$ 
supports these results and provides reasonable explanatory power for variation in working capital as the highest one is found in Bahrain (77.5\%) and the lowest one is found in Oman $(46.2 \%)$.

In general, these results are supported by Dechow and Dichev (2002) with respect to the association between accruals and cash flows, but they are inconsistent with Leal et al. (2017) which found that accruals quality are affected by extreme values of SD of residual. Table 15 shows the results of the relationship between EQ-AQ and FI.

Table 15 Results of regression between $A Q$ and FI

\begin{tabular}{|c|c|c|c|c|c|c|c|c|c|c|c|c|}
\hline \multirow{2}{*}{ Country } & \multicolumn{2}{|c|}{ KSA } & \multicolumn{2}{|c|}{ OMN } & \multicolumn{2}{|c|}{ QAT } & \multicolumn{2}{|c|}{ BAH } & \multicolumn{2}{|c|}{ KUW } & \multicolumn{2}{|c|}{ UAE } \\
\hline & B & t-value & B & t-value & $\mathrm{B}$ & $\mathrm{t}$-value & $\mathrm{B}$ & t-value & B & t-value & $\mathrm{B}$ & t-value \\
\hline EQ (AQ) & $\begin{array}{c}-1.616 \\
(0.01)\end{array}$ & -2.584 & $\begin{array}{c}1.992 \\
(0.045)\end{array}$ & 1.672 & $\begin{array}{c}0.055 \\
(0.177)\end{array}$ & 1.368 & $\begin{array}{c}0.055 \\
(0.510)\end{array}$ & 0.662 & $\begin{array}{c}-0.006 \\
(0.967)\end{array}$ & -0.042 & $\begin{array}{c}0.010 \\
(0.098)\end{array}$ & 1.669 \\
\hline Big4 & $\begin{array}{c}0-.014 \\
(0.024)\end{array}$ & -2.261 & $\begin{array}{c}-0.031 \\
(0.000)\end{array}$ & -3.810 & $\begin{array}{c}0.012 \\
(0.116) \\
\end{array}$ & 0.102 & $\begin{array}{c}.044 \\
(0.000) \\
\end{array}$ & 4.417 & $\begin{array}{c}-0.184 \\
(0.434)\end{array}$ & -0.789 & $\begin{array}{c}0.013 \\
(0.333) \\
\end{array}$ & 0.972 \\
\hline Risk & $\begin{array}{c}0.011 \\
(0.001) \\
\end{array}$ & 3.201 & $\begin{array}{c}0.039 \\
(0.000) \\
\end{array}$ & 3.839 & $\begin{array}{c}-0.001 \\
(0.441) \\
\end{array}$ & -0.776 & $\begin{array}{c}-.033 \\
(0.002) \\
\end{array}$ & -3.164 & $\begin{array}{c}-0.012 \\
(0.893) \\
\end{array}$ & -0.135 & $\begin{array}{l}-0.002 \\
(0.744) \\
\end{array}$ & $0-.327$ \\
\hline Size & $\begin{array}{c}0.006 \\
(0.152) \\
\end{array}$ & 1.435 & $\begin{array}{c}0.292 \\
(0.722) \\
\end{array}$ & 0.356 & $\begin{array}{c}-0.007 \\
(0.002) \\
\end{array}$ & -3.215 & $\begin{array}{c}-.026 \\
(0.008) \\
\end{array}$ & -2.725 & $\begin{array}{c}0.484 \\
(0.024) \\
\end{array}$ & 2.323 & $\begin{array}{c}0.001 \\
(0.952) \\
\end{array}$ & 0.060 \\
\hline $\begin{array}{c}\mathrm{R} \\
\text { (Model) }\end{array}$ & \multicolumn{2}{|c|}{$0.162^{* *}$} & \multicolumn{2}{|c|}{$0.220^{* *}$} & \multicolumn{2}{|c|}{$0.450 * *$} & \multicolumn{2}{|c|}{$0.610^{* *}$} & \multicolumn{2}{|c|}{0.388} & \multicolumn{2}{|c|}{0.217} \\
\hline $\mathrm{R} 2$ & \multicolumn{2}{|c|}{0.026} & \multicolumn{2}{|c|}{0.048} & \multicolumn{2}{|c|}{0.203} & \multicolumn{2}{|c|}{0.372} & \multicolumn{2}{|c|}{0.151} & \multicolumn{2}{|c|}{0.047} \\
\hline F-value & \multicolumn{2}{|c|}{4.765} & \multicolumn{2}{|c|}{8.089} & \multicolumn{2}{|c|}{4.656} & \multicolumn{2}{|c|}{10.236} & \multicolumn{2}{|c|}{2.174} & \multicolumn{2}{|c|}{1.404} \\
\hline Sig. & \multicolumn{2}{|c|}{0.001} & \multicolumn{2}{|c|}{0.000} & \multicolumn{2}{|c|}{0.006} & \multicolumn{2}{|c|}{0.000} & \multicolumn{2}{|c|}{0.086} & \multicolumn{2}{|c|}{0.237} \\
\hline
\end{tabular}

Note. $* *$ Correlation is significant at the 0.01 level (2-tailed).

*Correlation is significant at the 0.05 level (2-tailed).

Table 15 shows that the regression model in KSA, Oman, Qatar, and Bahrain is significant at the 0.01 level, but it is insignificant in Kuwait and UAE. EQ-AQ has a significantly positive effect on attracting foreign investors only in Oman as the coefficient is 1.992 ( $\mathrm{p}$-value $<0.05$ ), and the $\mathrm{R}^{2}$ of AQ explains $4.8 \%$ of the variation of attracting foreign investors. This result indicates that foreign investors can use the earnings to predict future cash flows and which will attract more foreign investors. The model is inversely significant in KSA as the coefficient is -1.616 (p-value<0.05), and the $\mathrm{R}^{2}$ is $2.6 \%$. The result in KSA indicates that the foreign investors have doubts about the sing earnings of KSA firms to predict the future cash flow. H5 is accepted in Oman and rejected in KSA and other GCC countries. Risk has a positive effect ( 0.011 in KSA and 0.039 Oman), and firms audited by big 4 audit firms have a negative effect $(-0.014$ in KSA and -0.031 in Oman) as the coefficients are significant at 0.05 and 0.01.

The results of this measure in GCC (except for Oman and KSA) are not in line with An (2019) which did not find a significant association between FI and EQ-AQ. The results are (except for Oman and KSA) in line with Vo and Chu (2019) which found 
no clear evidence of the association between FI and EQ-AQ. The control variables have different effects on foreign investors, confirming the significance of these variables.

\section{Measuring and Analysis of EQ-SM and FI}

The required information to calculate the earnings smoothness is the NIBE and its $\mathrm{SD}$ and $\mathrm{CFO}$. Table 16 shows SD for all required variables.

Table 16 Descriptive Statistics and Measuring of Earnings Smoothness

\begin{tabular}{c|cccccc}
\hline \multirow{2}{*}{ Country } & KSA & OMN & QAT & BAH & KWU & UAE \\
\cline { 2 - 7 } & SD & SD & SD & SD & SD & SD \\
\hline NIBE & 0.784 & 0.738 & 0.550 & 0.720 & 0.729 & 0.643 \\
\hline CFO & 0.843 & 0.790 & 0.206 & 0.898 & 0.643 & 0.757 \\
\hline SM & 0.930 & 0.934 & 2.67 & 0.802 & 1.134 & 0.849 \\
\hline
\end{tabular}

The SD of smoothness in Bahrain (0.802) is the lower one among the GCC countries, indicating that EQ is good. The highest SD of smoothness is found in Qatar, indicating lower EQ.

Although earnings smoothness is discussed in relation to many variables such as earning management (Aflatooni \& Nikbakht, 2010), firm value (Allayannis \& Simko, 2009), earnings informativeness (Cheng \& Li, 2014), and stock price (Lyimo, 2014), there is limited evidence that smoothness practices are either desirable or not in GCC countries. For example, Shubita (2015) found that income smoothing improves EQ, but we did not find any reversed evidence against this association. The interpretation of a higher degree of smoothness is that the managers in GCC firms exercise the practices of earnings smoothness to reduce the fluctuations in earnings. However, this result leads to an increased degree of smoothness, which makes the SD high. This proxy of EQ is less useful for stakeholders because they have less knowledge about earnings management in GCC-listed firms.

Table 17 shows the results of the relationship between EQ-SM and FI. 
Table 17 Regression Results between SM and FI

\begin{tabular}{|c|c|c|c|c|c|c|c|c|c|c|c|c|}
\hline \multirow{2}{*}{ Country } & \multicolumn{2}{|c|}{ KSA } & \multicolumn{2}{|c|}{ OMN } & \multicolumn{2}{|c|}{ QAT } & \multicolumn{2}{|c|}{ BAH } & \multicolumn{2}{|c|}{ KWU } & \multicolumn{2}{|c|}{ UAE } \\
\hline & B & t-value & B & t-value & B & t-value & B & t-value & B & t-value & B & t-value \\
\hline $\begin{array}{l}\mathrm{EQ}(\mathrm{SM}) \& \\
\text { sig. }\end{array}$ & $\begin{array}{c}-0.002 \\
(0.440)\end{array}$ & -0.772 & $\begin{array}{c}-0.003 \\
(0.649) \\
\end{array}$ & -0.456 & $\begin{array}{c}0.001 \\
(0.656)\end{array}$ & 0.448 & $\begin{array}{c}0.003 \\
(0.658) \\
\end{array}$ & 0.043 & $\begin{array}{l}-0.046 \\
(0.722) \\
\end{array}$ & -0.358 & $\begin{array}{c}0.020 \\
(0.090)\end{array}$ & 1.710 \\
\hline Big4 & $\begin{array}{l}-0.013 \\
(0.043)\end{array}$ & -2.027 & $\begin{array}{c}0.041 \\
(0.000)\end{array}$ & 3.901 & $\begin{array}{c}0.111 \\
(0.000)\end{array}$ & 3.255 & $\begin{array}{c}0.046 \\
(0.000)\end{array}$ & 4.751 & $\begin{array}{l}-0.180 \\
(0.439)\end{array}$ & -0.780 & $\begin{array}{c}0.018 \\
(0.217)\end{array}$ & 1.241 \\
\hline Risk & $\begin{array}{c}0.009 \\
(0.005)\end{array}$ & 2.806 & $\begin{array}{c}0.322 \\
(0.718)\end{array}$ & 0.362 & $\begin{array}{c}0.017 \\
(0.883)\end{array}$ & 0.148 & $\begin{array}{l}-0.031 \\
(0.004)\end{array}$ & -2.988 & $\begin{array}{l}-0.015 \\
(0.856)\end{array}$ & -0.170 & $\begin{array}{l}-0.003 \\
(0.591)\end{array}$ & -0.539 \\
\hline Size & $\begin{array}{c}0.004 \\
(0.384\end{array}$ & 0.671 & $\begin{array}{c}-0.031 \\
(0.000)\end{array}$ & -3.756 & $\begin{array}{c}-0.005 \\
(0.314)\end{array}$ & -0.436 & $\begin{array}{c}-0.021 \\
(0.000)\end{array}$ & -3.934 & $\begin{array}{c}0.463 \\
(0.021)\end{array}$ & 2.383 & $\begin{array}{c}0.009 \\
(0.307)\end{array}$ & 1.027 \\
\hline R (Model) & \multicolumn{2}{|c|}{$0.134^{*}$} & \multicolumn{2}{|c|}{$0.211^{* *}$} & \multicolumn{2}{|c|}{0.055} & \multicolumn{2}{|c|}{0.608} & \multicolumn{2}{|c|}{0.391} & \multicolumn{2}{|c|}{0.219} \\
\hline $\mathrm{R} 2$ & \multicolumn{2}{|c|}{0.018} & \multicolumn{2}{|c|}{0.044} & \multicolumn{2}{|c|}{0.003} & \multicolumn{2}{|c|}{0.370} & \multicolumn{2}{|c|}{0.153} & \multicolumn{2}{|c|}{0.048} \\
\hline F-value & \multicolumn{2}{|c|}{3.218} & \multicolumn{2}{|c|}{7.413} & \multicolumn{2}{|c|}{0.113} & \multicolumn{2}{|c|}{10.141} & \multicolumn{2}{|c|}{2.211} & \multicolumn{2}{|c|}{1.440} \\
\hline Sig. & \multicolumn{2}{|c|}{$0.012 *$} & \multicolumn{2}{|c|}{0.000} & \multicolumn{2}{|c|}{0.893} & \multicolumn{2}{|c|}{0.000} & \multicolumn{2}{|c|}{0.081} & \multicolumn{2}{|c|}{0.225} \\
\hline
\end{tabular}

Note. $* *$ Correlation is significant at the 0.01 level (2-tailed).

*Correlation is significant at the 0.05 level (2-tailed).

Table 17 shows that the model of EQ-SM and FI is significant in KSA, Oman, and Bahrain at 0.05 and 0.01, but it is insignificant in Qatar, Kuwait, and UAE. The significance of the model is because the control variables as the coefficients of EQ-SM are insignificant in all GCC countries. The result of this measure is matched with what we predicted. $\mathrm{H} 6$ is accepted in that using earnings smoothness will not attract more foreign investors and that earnings smoothness is not a desirable practice. With less knowledge about this measure in GCC region, foreign investors are unsure whether earnings smoothness is a consequence of earnings management or a good indicator for future cash flow.

The result of this measure is not in line with Jung et al. (2020) which found a positive association between FI and income smoothing as foreign investors demand more sustainable earnings, and this can be done by earnings smoothness. This result is also not in line with Rountree et al. (2008) which found that investors evaluate earnings smoothness negatively.

\section{Measuring and Analysis of EQ-TRL and FI}

The required information to calculate the TRL is the NIBE, Ret, and dummy variables. Table 18 shows all required variables. 
Table 18 Descriptive Statistics and Measuring of Timely Recognition Losses

\begin{tabular}{|c|c|c|c|c|c|c|c|c|c|c|c|c|}
\hline \multirow{2}{*}{ Country } & \multicolumn{2}{|c|}{$\mathrm{KSA}$} & \multicolumn{2}{|c|}{ OMN } & \multicolumn{2}{|c|}{ QAT } & \multicolumn{2}{|c|}{ BAH } & \multicolumn{2}{|c|}{ KWU } & \multicolumn{2}{|c|}{ UAE } \\
\hline & Mean & SD & Mean & SD & Mean & SD & Mean & SD & Mean & SD & Mean & SD \\
\hline NIBE & 1.61 & 0.784 & 0.615 & 0.738 & 1.99 & 0.550 & 1.20 & 0.720 & 1.12 & 0.729 & 1.65 & 0.643 \\
\hline Return(Ret) & 1.35 & 0.495 & 1.29 & 0.660 & 1.32 & 0.531 & 1.08 & 0.421 & 1.18 & 0.549 & 1.43 & 0.575 \\
\hline (Ret*D) & 1.03 & 1.44 & 0.83 & 1.41 & 0.76 & 0.161 & 0.71 & 1.76 & 0.96 & 0.06 & 1.05 & 0.014 \\
\hline $\begin{array}{l}\text { EQ(TRL)- } \\
\beta 1\end{array}$ & \multicolumn{2}{|c|}{0.898} & \multicolumn{2}{|c|}{0.249} & \multicolumn{2}{|c|}{2.121} & \multicolumn{2}{|c|}{-4.857} & \multicolumn{2}{|c|}{-0.074} & \multicolumn{2}{|c|}{1.578} \\
\hline
\end{tabular}

The higher $\beta 1$ is found in Qatar, which means that the financial reporting of Qatarlisted firms is more useful than that of the other GCC countries. The lowest value of $\beta 1$ which is found in Bahrain, indicates that the financial statements of Bahraini-listed firms are less timely in recognising the incurred losses in earnings and that this does not provide useful information for the investors.

This result indicates that the GCC firms exercise loss recognition timeliness, and in some countries, the evidence shows more timely loss recognition.

Table 19 shows the results of the relationship between EQ-TRL and FI.

Table 19 Regression Results between TRL and FI

\begin{tabular}{|c|c|c|c|c|c|c|c|c|c|c|c|c|}
\hline \multirow{2}{*}{$\begin{array}{l}\text { Country } \\
\text { Variables }\end{array}$} & \multicolumn{2}{|c|}{ KSA } & \multicolumn{2}{|c|}{ OMN } & \multicolumn{2}{|c|}{ QAT } & \multicolumn{2}{|c|}{$\mathrm{BAH}$} & \multicolumn{2}{|c|}{ KWU } & \multicolumn{2}{|c|}{ UAE } \\
\hline & B & $\begin{array}{c}\mathrm{t}- \\
\text { value }\end{array}$ & B & $\begin{array}{c}\mathrm{t}- \\
\text { value }\end{array}$ & B & t-value & B & $\begin{array}{c}\mathrm{t}- \\
\text { value }\end{array}$ & B & t-value & B & $\begin{array}{c}\mathrm{t}- \\
\text { value }\end{array}$ \\
\hline $\begin{array}{c}\mathrm{EQ}(\mathrm{CON}) \\
\& \text { sig. }\end{array}$ & $\begin{array}{c}0.042 \\
(0.281)\end{array}$ & 1.080 & $\begin{array}{l}-0.001 \\
(0.993)\end{array}$ & -0.009 & $\begin{array}{c}0.002 \\
(0.767)\end{array}$ & 0.298 & $\begin{array}{l}-0.154 \\
(0.197)\end{array}$ & -1.307 & $\begin{array}{c}0.05 \\
(0.497)\end{array}$ & 0.685 & $\begin{array}{c}0.035 \\
(0.719)\end{array}$ & 0.360 \\
\hline Big4 & $\begin{array}{l}-0.015 \\
(0.024)\end{array}$ & -2.257 & $\begin{array}{c}0.042 \\
(0.000)\end{array}$ & 4.086 & $\begin{array}{c}0.236 \\
(0.000)\end{array}$ & 3.742 & $\begin{array}{c}0.035 \\
(0.001)\end{array}$ & 3.635 & $\begin{array}{l}-0.137 \\
(0.572) \\
\end{array}$ & -0.569 & $\begin{array}{c}0.012 \\
(0.410)\end{array}$ & 0.828 \\
\hline Risk & $\begin{array}{c}0.010 \\
(0.004)\end{array}$ & 2.913 & $\begin{array}{c}0.013 \\
(0.729)\end{array}$ & 0.347 & $\begin{array}{c}0.053 \\
(0.623)\end{array}$ & 0.494 & $\begin{array}{l}-0.025 \\
(0.017) \\
\end{array}$ & -2.455 & $\begin{array}{c}0.001 \\
(0.991)\end{array}$ & 0.012 & $\begin{array}{l}-0.004 \\
(0.497)\end{array}$ & -0.681 \\
\hline Size & $\begin{array}{c}0.006 \\
(0.238) \\
\end{array}$ & 1.181 & $\begin{array}{c}-0.03 \\
(0.000)\end{array}$ & -3.723 & $\begin{array}{l}-0.004 \\
(0.001)\end{array}$ & -3.573 & $\begin{array}{l}-0.013 \\
(0.024) \\
\end{array}$ & -2.329 & $\begin{array}{c}0.501 \\
(0.011)\end{array}$ & 2.638 & $\begin{array}{c}0.007 \\
(0.456)\end{array}$ & 0.748 \\
\hline $\mathrm{R}(\mathrm{EQ} * \mathrm{FI})$ & \multicolumn{2}{|c|}{$0.153 * *$} & \multicolumn{2}{|c|}{$0.210 * *$} & \multicolumn{2}{|c|}{$0.389 * *$} & \multicolumn{2}{|c|}{$0.562 * *$} & \multicolumn{2}{|c|}{0.398} & \multicolumn{2}{|c|}{0.157} \\
\hline $\mathrm{R} 2$ & \multicolumn{2}{|c|}{0.023} & \multicolumn{2}{|c|}{0.044} & \multicolumn{2}{|c|}{0.151} & \multicolumn{2}{|c|}{0.316} & \multicolumn{2}{|c|}{0.159} & \multicolumn{2}{|c|}{0.025} \\
\hline F-value & \multicolumn{2}{|c|}{3.757} & \multicolumn{2}{|c|}{7.359} & \multicolumn{2}{|c|}{4.399} & \multicolumn{2}{|c|}{6.230} & \multicolumn{2}{|c|}{2.312} & \multicolumn{2}{|c|}{0.725} \\
\hline Sig. & \multicolumn{2}{|c|}{0.005} & \multicolumn{2}{|c|}{0.000} & \multicolumn{2}{|c|}{0.007} & \multicolumn{2}{|c|}{0.000} & \multicolumn{2}{|c|}{0.071} & \multicolumn{2}{|c|}{0.577} \\
\hline
\end{tabular}

Note. $* *$ Correlation is significant at the 0.01 level (2-tailed).

*Correlation is significant at the 0.05 level (2-tailed).

Table 19 shows that the model of EQ-TRL and FI is significant in KSA, Oman, Qatar, and Bahrain at 0.05 and 0.01, but it is insignificant in Kuwait and UAE. The significance of the model is because the control variables as the coefficients of EQ-TRL are insignificant in all GCC countries. $\mathrm{H} 7$ is rejected, and loss recognition timeliness does not attract foreign investors.

Although the results indicate that the GCC firms exercise loss recognition timeliness, foreign investors seem not to be influenced by this measure. One possible 
reason is that the GCC firms report less loss. In addition, the managers of GCC firms tend to recognise sooner their financial loses to reduce the fluctuations in earnings which then improve EQ. Moreover, the total assets in GCC firms are financed by external debts with an average of $72 \%$, which makes foreign investors very sensitive towards future cash flows. If the loss recognition becomes timely, earnings management seems to be considered by foreign investors. The result of this measure is not in line of Dobre et al. (2015) which found the loss recognition timeliness is a positive exercise that improves EQ.

\section{Measuring and Analysis of EQ-CON and FI}

The required information to calculate the conservatism is the NIBE, CFO, TA, and dummy variable. Table 20 shows all required variables.

Table 20 Descriptive Statistics and Measuring of Conservatism

\begin{tabular}{|c|c|c|c|c|c|c|c|c|c|c|c|c|}
\hline \multirow{2}{*}{ Country } & \multicolumn{2}{|c|}{ KSA } & \multicolumn{2}{|c|}{ OMN } & \multicolumn{2}{|c|}{ QAT } & \multicolumn{2}{|c|}{ BAH } & \multicolumn{2}{|c|}{ KWU } & \multicolumn{2}{|c|}{ UAE } \\
\hline & Mean & SD & Mean & SD & Mean & SD & Mean & SD & Mean & SD & Mean & SD \\
\hline NIBE (E) & 1.61 & 0.784 & 0.615 & 0.738 & 1.99 & 0.550 & 1.20 & 0.720 & 1.12 & 0.729 & 1.65 & 0.643 \\
\hline CFO & 1.76 & 0.843 & 0.733 & 0.790 & 0.299 & 0.206 & 1.30 & 0.898 & 1.37 & 0.643 & 1.87 & 0.757 \\
\hline TA & 2.865 & 0.712 & 1.82 & 0.608 & 3.26 & 0.629 & 2.32 & 0.69 & 2.65 & 0.617 & 3.06 & 0.338 \\
\hline $\begin{array}{c}\text { EQ (CON)- } \\
\beta 3\end{array}$ & \multicolumn{2}{|c|}{0.301} & \multicolumn{2}{|c|}{-0.783} & \multicolumn{2}{|c|}{-0.678} & \multicolumn{2}{|c|}{-0.474} & \multicolumn{2}{|c|}{-0.165} & \multicolumn{2}{|c|}{0.503} \\
\hline
\end{tabular}

In general, the degree of conservatism $(\beta 3)$ is less in all the GCC countries as the highest one is found in UAE (0.503), and the lowest one is in Oman (-0.783). These values are low compared with those of other countries, such as South Korea (An, 2017) and Indonesia (Sari \& Sarumpaet, 2019). One of the most important reasons for this lower degree is that most listed firms in GCC countries apply IFRS in preparing their financial statements which require less degree of conservatism.

Table 21 shows the results of the relationship between EQ-CON and FI. 
Table 21 Regression Results between CON and FI

\begin{tabular}{|c|c|c|c|c|c|c|c|c|c|c|c|c|}
\hline \multirow{2}{*}{ variables } & \multicolumn{2}{|c|}{ KSA } & \multicolumn{2}{|c|}{ OMN } & \multicolumn{2}{|c|}{ QAT } & \multicolumn{2}{|c|}{$\mathrm{BAH}$} & \multicolumn{2}{|c|}{ KWU } & \multicolumn{2}{|c|}{ UAE } \\
\hline & $\mathrm{b}$ & t-value & B & t-value & $\mathrm{b}$ & t-value & $\mathrm{b}$ & t-value & $\mathrm{b}$ & t-value & $\mathrm{b}$ & t-value \\
\hline $\begin{array}{c}\mathrm{EQ}(\mathrm{CON}) \\
\& \text { sig. }\end{array}$ & $\begin{array}{c}-0.087 \\
(0.026)\end{array}$ & -2.229 & $\begin{array}{c}-0.017 \\
(0.652)\end{array}$ & -0.451 & $\begin{array}{c}0.006 \\
(0.050) \\
\end{array}$ & 1.995 & $\begin{array}{c}0.001 \\
(0.881)\end{array}$ & 0.150 & $\begin{array}{c}-0.098 \\
(0.793) \\
\end{array}$ & -0.265 & $\begin{array}{c}-0.002 \\
(0.877) \\
\end{array}$ & -0.155 \\
\hline big4 & $\begin{array}{l}-0.015 \\
(0.017)\end{array}$ & -2.384 & $\begin{array}{c}0.042 \\
(0.000)\end{array}$ & 4.103 & $\begin{array}{c}0.251 \\
(0.000)\end{array}$ & 2.160 & $\begin{array}{c}0.010 \\
(0.000)\end{array}$ & 5.020 & $\begin{array}{c}0.404 \\
(0.181)\end{array}$ & 1.367 & $\begin{array}{c}0.017 \\
(0.275)\end{array}$ & 1.098 \\
\hline Risk & $\begin{array}{c}0.010 \\
(0.003)\end{array}$ & 3.033 & $\begin{array}{c}0.014 \\
(0.726)\end{array}$ & 0.351 & $\begin{array}{c}-0.012 \\
(0.916)\end{array}$ & -0.106 & $\begin{array}{c}-0.034 \\
(0.001)\end{array}$ & -3.310 & $\begin{array}{c}0.199 \\
(0.088)\end{array}$ & 1.758 & $\begin{array}{c}0.010 \\
(0.293)\end{array}$ & 1.056 \\
\hline Size & $\begin{array}{c}0.006 \\
(0.157) \\
\end{array}$ & 1.416 & $\begin{array}{c}-0.030 \\
(0.000) \\
\end{array}$ & -3.729 & $\begin{array}{c}-0.006 \\
(0.000) \\
\end{array}$ & -4.147 & $\begin{array}{l}-0.022 \\
(0.000) \\
\end{array}$ & -4.209 & $\begin{array}{c}0.830 \\
(0.000) \\
\end{array}$ & 03.979 & $\begin{array}{c}-0.004 \\
(0.525) \\
\end{array}$ & -0.638 \\
\hline R (model) & \multicolumn{2}{|c|}{0.155} & \multicolumn{2}{|c|}{$0.211^{* *}$} & \multicolumn{2}{|c|}{$0.440^{* *}$} & \multicolumn{2}{|c|}{$0.632 * *$} & \multicolumn{2}{|c|}{$0.602 * *$} & \multicolumn{2}{|c|}{0.203} \\
\hline $\mathrm{R}^{2}$ & \multicolumn{2}{|c|}{0.024} & \multicolumn{2}{|c|}{0.044} & \multicolumn{2}{|c|}{0.194} & \multicolumn{2}{|c|}{0.399} & \multicolumn{2}{|c|}{0.362} & \multicolumn{2}{|c|}{0.041} \\
\hline F-value & \multicolumn{2}{|c|}{4.331} & \multicolumn{2}{|c|}{7.412} & \multicolumn{2}{|c|}{5.926} & \multicolumn{2}{|c|}{11.301} & \multicolumn{2}{|c|}{4.830} & \multicolumn{2}{|c|}{1.016} \\
\hline sig. & \multicolumn{2}{|c|}{0.003} & \multicolumn{2}{|c|}{0.000} & \multicolumn{2}{|c|}{0.001} & \multicolumn{2}{|c|}{0.000} & \multicolumn{2}{|c|}{0.003} & \multicolumn{2}{|c|}{0.403} \\
\hline
\end{tabular}

Note. $* *$ Correlation is significant at the 0.01 level (2-tailed).

*Correlation is significant at the 0.05 level (2-tailed).

Table 21 shows that the model is significant in all GCC countries at 0.01 except for UAE, in which the model is insignificant. The level of conservatism has a significantly negative effect on attracting foreign investors only in KSA as the coefficient is -0.087 ( $p$-value $<0.05$ ), which indicates that the increase in conservatism does not attract foreign investors. As we predicted, H7 is accepted (except in KSA) as the accounting conservatism practices are rarely used in GCC countries, and conservatism is not used as a tool to protect the investors, and foreign investors have no power in the board of directors in GCC firms. For example, in KSA, as Naif and Ali (2019), the capital market 'Tadawul' is considered one of the good markets for FI, but many issues are pending and not implemented to attract more foreign investors. This result is supported by An (2019) which found no relationship between FI and EQ-CON, but it is not in line with Khalil et al. (2020) which found that conservatism practices are attractive practices for foreign investors. In general, foreign investors prefer to invest in firms audited by the big 4 , have less risk, and are small in size as conservatism is low.

\section{Ranking of EQ Measures}

The ranking of EQ measures helps investors build their decision models carefully. Perotti and Wagenhofer (2014) discussed that there is little discussion in the literature addressing this point as this depends on the measures themselves and the association between these measures and other variables. Lyimo (2014) used consistency among the EQ measures as more consistency indicates good measures. Therefore, researchers can use their own method to rank the EQ measures.

In this study, we ranked the EQ measures in the respective country based on the high and low EQ measures in that country. Table 22 shows the results of high and low EQ measures in each country. 
Table 22 Ranks of EQ by Country

\begin{tabular}{|c|c|c|c|c|c|c|c|c|c|c|c|c|}
\hline \multirow{2}{*}{ EQ measure } & \multicolumn{2}{|c|}{ KSA } & \multicolumn{2}{|c|}{ OMN } & \multicolumn{2}{|c|}{ QAT } & \multicolumn{2}{|c|}{ BAH } & \multicolumn{2}{|c|}{ KUW } & \multicolumn{2}{|c|}{ UAE } \\
\hline & Value & Rank & Value & Rank & Value & Rank & Value & Rank & Value & Rank & Value & Rank \\
\hline $\begin{array}{c}\text { EQ(PER)- } \\
\beta \\
\end{array}$ & 0.333 & 6 & 0.610 & 1 & 0.490 & 4 & 0.504 & 3 & 0.581 & 2 & 0.405 & 5 \\
\hline $\mathrm{EQ}(\mathrm{P})-\mathrm{R}^{2}$ & $10.8 \%$ & 6 & $38.2 \%$ & 3 & $36.8 \%$ & 4 & $39.4 \%$ & 1 & $38.6 \%$ & 2 & $21.8 \%$ & 5 \\
\hline $\begin{array}{c}\mathrm{EQ}(\mathrm{VR})- \\
\mathrm{R}^{2} \\
\end{array}$ & $21.9 \%$ & 6 & $53.7 \%$ & 4 & $67.1 \%$ & 3 & $71.1 \%$ & 2 & $72 \%$ & 1 & $27.4 \%$ & 5 \\
\hline $\begin{array}{c}\text { EQ(ERC)- } \\
\beta\end{array}$ & 0.058 & 2 & 0.268 & 1 & -0.228 & 6 & -0.064 & 3 & -0.091 & 4 & -0.222 & 5 \\
\hline $\mathrm{EQ}(\mathrm{ESI})$ & 1.33 & 4 & 1.52 & 5 & 1.25 & 2 & 1.28 & 3 & 1.59 & 6 & 1.24 & 1 \\
\hline EQ(AQ) & 0.577 & 6 & 0.504 & 3 & 0.504 & $2 *$ & 0.348 & 1 & 0.457 & 4 & 0.559 & 5 \\
\hline $\mathrm{EQ}(\mathrm{SM})$ & 0.930 & 3 & 0.934 & 4 & 2.67 & 6 & 0.802 & 1 & 1.134 & 5 & 0.849 & 2 \\
\hline $\begin{array}{c}\text { EQ(TRL)- } \\
\beta 1\end{array}$ & 0.898 & 3 & 0.249 & 4 & 2.121 & 1 & -4.857 & 5 & -0.074 & 6 & 1.578 & 2 \\
\hline $\begin{array}{c}\mathrm{EQ}(\mathrm{CON})- \\
\beta 3 \\
\end{array}$ & 0.301 & 5 & -0.783 & 1 & -0.678 & 2 & -0.474 & 3 & -0.165 & 4 & 0.503 & 6 \\
\hline
\end{tabular}

Note. ${ }^{*} \mathrm{R}^{2}$ of $\mathrm{AQ}$ in Qatar is more than Oman.

Table 22 shows the degree of each EQ measure. Firstly, Oman and Bahrain never came at the last (sixth) rank, which means that the earnings have higher quality in these two countries. In addition, Oman and Bahrain came in the first rank three times out of nine; Qatar, UAE, and Kuwait, one time. KSA never came first in all EQ measures, which means that the EQ in this country is questionable.

In terms of accounting-based measures, Oman and Bahrain are the better countries that focus on the sustainability of earnings. Bahrain, Qatar, and Oman are the better three countries in terms of the quick conversion of earnings into cash flow. In addition, the accruals contain lower estimation error which is a good indicator for the protection of investors. With respect to earnings smoothness, all GCC countries have a problem of earnings volatility as the degree of smoothness is high, making EQ questionable. ESI refers to the case that the firms' actual results meet and beat analysts' expectations. However, the high value of earnings surprise in all GCC countries makes EQ questionable. With conservatism as a tool to protect the stakeholders, Oman is the better country that protects the investors, followed by Qatar and Bahrain. The protection of investors in UAE, KSA, and Kuwait is an issue, though.

Regarding market-based measures, as all GCC countries have bad indicators about value relevance in terms of ERC, the information that the investors need to build their decision model is an issue. Nevertheless, the earnings per share and book value of the share reflect the share price. Qatar and UAE rank the first and second for the measure of loss recognition timeliness, indicating that the stakeholders can assess the management's optimism about the future. 


\section{DISCUSSION OF RESULTS}

The GCC countries struggle to attract more foreign investment to compensate for the ongoing decrease in oil and gas prices and to implement the economic diversification policy. Due to this situation, Khayat (2020) indicates that GCC countries start to implement an economic diversification policy. ALHarithi (2018) points out that GCC policymakers make foreign direct investment one of the main plans to diversify GCC countries' economies and attract additional foreign portfolio investments. Aziz and Mishra (2016) and Hussein (2009) find that foreign investments positively and significantly affect GCC economies. Accordingly, GCC countries improve foreign investments' policy and regulatory environment to attract more foreign investors, which reflects the countries' economic solid prospects. On the other side, one of the most important steps on this road is improving the financial reporting quality through enhancing EQ. Typically, foreign investors need relevant and reliable information to improve their investment decision models, and this can be done through using multiple, competing, and integrated EQ measures. As the GCC markets are relatively new for foreign investors, this study aims to provide a wide range of relevant and reliable information about EQ. In terms of earnings persistence, all GCC have high and sustainable earnings, but only the model in Oman positively affects attracting foreign investors as Oman is more stable than other GCC countries. Pauceanu (2016) finds that political and economic stability is one factor to motivate foreign investors to invest in Oman. Foreign investors seem to have a problem using the relationship between past and future earnings in the other GCC countries as they fail to use earnings persistence information and usually underestimate earnings. This result is supported by Ben-Nasr et al. (2015) which found that more stable countries refer to higher EQ. Also, this result is consistent with the findings of Vo and Chu (2019) and An (2019) which find a significant positive association between PER and FI as using PER improves the decisions of FI. The predictability of earnings positively affects attracting FI only in Oman, indicating that foreign investors can use the current earnings to predict future earnings. On the contrary, they cannot do the same in other GCC countries as the earnings components are less important than other data such as cash flow and market data.

In terms of accruals, EQ in Oman has a positive effect on attracting foreign investors. This result gives more credibility to accounting information when deciding about foreign investment, and it serves as a good indicator for protecting foreign investors. The situation in KSA is different as EQ has a negative effect on attracting FI, making accounting information questionable. The surprising result of Bahrain, as the $\mathrm{AQ}$, is less than that in other GCC countries, but it does not affect attracting foreign investors owing to political issues in the country from 2011 onward (Nuruzzaman, 2013). 
GCC countries (except for Oman) have difficulties in converting the accruals into cash flows quickly and completely. This is because EQ-AQ has a significantly positive effect on attracting foreign investors only in Oman as the coefficient is 1.992 ( $\mathrm{p}$-value $<0.05$ ), and the R2 of AQ explains $4.8 \%$ of the variation of attracting foreign investors. The results of AQ are not in line with Bloomfield et al. (2015) and An (2019) which found that good EQ is there when the accruals are more quickly and completely converted into cash flow.

In terms of ERC, EQ is very low in all GCC countries, indicating that the informativeness of financial reporting is a matter of concern as the market's reaction to the accounting information is low. However, ERC in Oman and Kuwait has a positive association with foreign investors, which means that the foreign investors use the accounting information to predict the variations in share price as these variations are associated with the earnings announcements. In addition, foreign investors predict to achieve more profits in Oman and Kuwait as these countries are neutral against the GCC political crisis in 2017 (Pradhan, 2017). In relation to another value relevance measure, EQ of Kuwaiti firms is matched with $\mathrm{R}^{2}$ as a value relevance measure which means that foreign investors can use the book value and EPS to predict the share price. This result is consistent with An (2019) finding, which finds a positive relationship between value relevance and FI. This result is supported by Alfraih and Alanezi (2015) which found that the financial reporting of non-financial Kuwaiti firms is associated positively with investors. This result is also supported by Kumar and Singh (2013) which found that the investors in the Omani capital market can achieve abnormal returns using the accounting information. In KSA, both measures of value relevance have a negative association with foreign investors, indicating a weak market reaction to financial reporting and the relationship between book value, EPS, and share price. The result of EQ in KSA is supported by Asiri and Alzeera (2013) which found that the KSA capital market is weak and that all investors are not expected to generate abnormal returns. In the UAE, value relevance negatively affects attracting foreign investors, indicating that they do not use the accounting information to build their investment decisions. Marashdeh and Shrestha support this result (2008) which found that the efficiency market of UAE is weak and that the reaction to the earning information is also weak. However, the result of this EQ (value relevance) in QAT and BAH is consistent with the findings of Vo and Chu (2019), which find no clear evidence about the relationship between this measure of EQ and FI.

In all GCC countries, EQ in terms of ESI does not affect attracting foreign investors, which means that there are differences between earnings reported and analysts' predictions. As a new entry into the market, foreign investors depend on analysts' 
expectations more than the earnings reported by the firms because they have less information, low knowledge about the market, and a high level of uncertainty.

In terms of earnings smoothness, there is no association between EQ-SM and FI, indicating that foreign investors do not prefer earnings smoothness as they consider it a type of earnings management. Basically, the information environment in GCC is categorized as less informative, so foreign investors encounter difficulties when trying to understand whether the earnings smoothness practices improve earnings informativeness. This result is not in line with Jung et al. (2020) which found that foreign investors demand earnings smoothness to improve the earnings informativeness in Korea.

Although loss recognition timeliness is not common in GCC firms, the degree of EQ-TRL is high in some countries because the GCC firms report less loss as they have good experience with the profit. The unknown effect of EQ-TRL in the period of high persistence of earnings, as Basu (1997) pointed out, affects the decision usefulness of earnings. In GCC, we agree with this conclusion as the effect of EQ-TRL is unknown. No evidence confirms that this effect is positive or negative from the FI perspective.

Finally, the effect of conservatism on attracting foreign investors is insignificant in all GCC countries except for KSA as the coefficient of conservatism is negative and significant. This is because KSA firms have good experience with accounting conservatism, as pointed out by Abdul-Malik (2017), which found that conservatism positively affects the financial reporting quality in KSA. In other countries, the level of conservatism is reasonable as the governmental authorities responsible for the capital market have enough power to force firms to present a reasonable level of conservatism, as pointed out by Hamdan et al. (2011) in Kuwait. This result is consistent with An (2019), which finds no relationship between conservatism and FI.

\section{CONCLUSIONS}

This study is one of the first to explore a comprehensive set of EQ measures in the GCC region. It has two main objectives. The first is to measure EQ in GCC countries using nine proxies: persistence, predictability, accrual quality, earnings smoothness, earnings surprise indicator, value relevance (two proxies), and loss recognition timeliness and conservatism. The second one is to examine the effect of these nine proxies on attracting foreign investors.

\section{Results of EQ Proxies in GCC Countries}

Using a large sample of GCC non-financial firms throughout 2008-2016, we first confirm that EQ in terms of user needs has higher quality in Oman for earnings persistence and ERC, Kuwait for value relevance (R2), Bahrain for predictability, and 
UAE for ESI. EQ in terms of earnings persistence, predictability, value relevance (R2) is low in KSA, whereas EQ is low in Qatar in terms of ERC and in Kuwait in terms of ESI. EQ has higher predictability in Bahrain and Oman, but the predictability is low in KSA.

In terms of investor protection, EQ is higher in Bahrain and Kuwait with respect to accrual quality. EQ is higher in Bahrain and UAE with respect to earnings smoothness, it is high in terms of TRL in Qatar and UAE, and finally, it is high in Oman in terms of conservatism. Foreign investors have less protection in terms of accrual quality in KSA, smoothness in Kuwait, TRL in Bahrain, and conservatism in UAE.

\section{Foreign Investors and EQ}

Foreign investors can take their decision in Oman as persistence and predictability positively affect attracting FI but not in other GCC countries. Predictability has a negative effect on attracting FI in KSA and Kuwait, which means that this measure is not a good indicator for FI and cannot use the current earnings to predict future earnings. ERC has a positive effect on attracting FI in Oman and Kuwait, indicating that FI can predict the variations in share price, but it has a negative effect in KSA as FI cannot predict these variances in share price. Value relevance in Kuwait positively affects FI, which means a good relationship between book value, EPS, and share price. However, this relationship is negative in KSA, Oman, and UAE, indicating that foreign investors have doubts about increasing share prices. Accruals quality positively affects attracting FI in Oman, indicating that accrual can be quickly converted into cash. Accrual needs more time to convert into cash in KSA, though, as the association between accrual and FI is negative. Conservatism negatively affects KSA, indicating that the firms should keep reasonable conservatism to attract more foreign investors. Finally, ESI, SM, and TRL do not affect attracting foreign investors to GCC capital markets. Control variables have different effects on foreign investors, confirming the significance of these variables. They also improve the regression models. Table 23 summarized the results of the effect of EQ proxies on FI in all six GCC countries. 
Table 23 Summary of Results of the Study

\begin{tabular}{c|ccccccc}
\hline EQ & Expected & KSA & OMN & QAT & BAH & KUW & UAE \\
\hline PER & + & No effect & + & No effect & No effect & No effect & No effect \\
\hline P & + & - & + & No effect & No effect & - & No effect \\
\hline VR-ERC & + & - & + & No effect & No effect & + & No effect \\
\hline VR-R & + & - & - & No effect & No effect & + & - \\
\hline ESI & + & No effect & No effect & No effect & No effect & No effect & No effect \\
\hline AQ & + & - & + & No effect & No effect & No effect & No effect \\
\hline SM & No sign & No effect & No effect & No effect & No effect & No effect & No effect \\
\hline TRL & + & No effect & No effect & No effect & No effect & No effect & No effect \\
\hline CON & No sign & - & No effect & No effect & No effect & No effect & No effect \\
\hline
\end{tabular}

In general, the results of the effect of EQ on FI are different in all six GGC countries. Firstly, the study results match all GCC countries' expected SM (smoothness) and CON (conservatism) results. The results of PER match with the expected results only in OMN. Also, the results of P are different across GCC countries as it matches with the expected results in OMN, unmatched in KSA and KUW, and no effect in QAT, $\mathrm{BAH}$, and UAE. The value relevance results in ERC match the expected results in OMN and KUW while it is negative in KSA and has no effect in BAH, UAE, and QAT. The value relevance in terms of R2 has the same result in KUW but is negative in KSA, OMN, and UAE. The results of ESI and TRL are unmatched with the expected results in all GCC countries as the expected result is positive, whereas the statistical result of this study is no effect. The results of AQ matches with the expected results in OMN and unmatched in other GCC countries. Finally, the results of the effect of conservatism on FI are matched in all GCC countries except for KSA as the effect is negative.

\section{Study Contributions}

This research intends to make four contributions. Firstly, this research is done in emerging markets, particularly GCC capital markets, where few studies on EQ are done. Secondly, notable measures commonly used to measure the quality of reported earnings include accrual quality, loss recognition timeliness, persistence, predictability, smoothness, timeliness, conservatism, and earnings surprise. As previously discussed, very limited proxies are used to measure EQ in GCC countries. Thirdly, all GCC countries issued new foreign investment laws and regulations to attract more institutional and individual investors. Hence, improving EQ is crucial to improve the disclosure and transparency of financial information. Finally, this study introduces a framework to measure and compare EQ as an across-the-board factor that plays an important role in influencing investors' decisions. This study complements existing 
research on the association between EQ and foreign investors. Most studies in this area aim to examine the effect of foreign investors on EQ (e.g., Khalil et al., 2020; Vo \& Chu, 2019), but very limited efforts are conducted to examine whether FI is influenced by different measures of EQ which is the main theme in this study.

\section{Policy Implications}

The findings of this study have several policy implications. Firstly, multiple EQ measures have different interpretations, and foreign investors should accept each measure carefully and according to their preferences. Secondly, foreign investors are interested in more relevant information as well as more reliable or protection information. Therefore, regulators of the capital market should use EQ measures as guidelines to improve the informativeness of financial reporting for better allocation of resources in capital markets. Thirdly, the regulators should increase the awareness and comprehensive understanding of the role of foreign ownership in GCC capital markets. Fourthly, the findings have implications for the managers of the firms as they should manage the EQ information carefully to avoid any misuse of each EQ measure. For example, if the managers decide to smooth the earnings, they should study the consequences of this decision on attracting foreign investors.

\section{Study Limitations and Future Studies}

There are several limitations to this study. Firstly, the study is based on the nonfinancial listed firms in GCC markets, excluding listed firms in the banking and financial sectors. The generalisation of findings to all sectors in the GCC capital markets may be problematic due to the different regulatory frameworks for these firms. Further study can be carried out in the banking and financial sectors. Secondly, the findings may also not be generalised to the other developing countries such as the Middle East region due to the different legal, institutional and economic environments. Further research can also be carried out in these regions. Thirdly, in calculating the EQ measures, the study uses some common measures in reputable studies. Nonetheless, other measures may give different results and interpretations, so future studies should use other EQ measures. Fourthly, the number of observations in each measure is different due to missing data, which may have a different effect on EQ. We advise completing the data by using the research database as well as the financial reports of the firms in each country. Finally, due to limited time and resources, some topics are not discussed in this study, such as the rank of EQ measures as the best measure and the relationships between the EQ measures. Future studies can pursue these topics. 


\section{REFERENCES}

Abdul-Malik, A. R. (2017). Investigating the relationship between corporate governance principles and accounting conservatism for companies listed on Saudi stock exchange. European Journal of Accounting Auditing and Finance Research, 5(9), 10-30.

Adetunji, S. A. (2016). The value relevance of earnings in the return-Earnings relation in the Nigerian deposit money banks. Cogent Business \& Management, 3(1), 1210276, 1-10. https://doi.org/10.1080/23311975.2016.1210276

Aflatooni, A., \& Nikbakht, Z. (2010). Income smoothing, real earning management and long-run stock returns. Business Intelligence Journal, 3(1), 55-73.

Ahn, H.-B., \& Kwon, G.-J. (2010). Earnings persistence and market reaction: Evidence from Korea. International Journal of Business and Management, 5(10), 10-19. https://doi.org/10.5539/ijbm.v5n10p10

Al-Amri, K., Al Shidi, S., Al Busaidi, M., \& Akguc, S. (2017). Real earnings management in public vs private firms in the GCC countries: A risk perspective. Journal of Applied Accounting Research, 18(2), 242-260. https://doi.org/10.1108/JAAR-11-2014-0124

Alfraih, M., \& Alanezi, F. (2015). The value relevance of mandatory corporate disclosures: Evidence from Kuwait. International Journal of Business and Finance Research, 9(3), 1-18.

ALHarithi, M. (2018). Determinants of foreign direct investment in Gulf Cooperation Council (GCC) region [Conferene presentation]. 10th Economics \& Finance Conference, Rome, Italy.

Ali, A., \& Hwang, L. S. (2000). Country-specific factors related to financial reporting and the value relevance of accounting data. Journal of Accounting Research, 38(1), 1-21. https://doi.org/10.2307/2672920

Allayannis, G., \& Simko, P. (2009). Earnings smoothing, analyst following and firm value. Available at SSRN: https://ssrn.com/abstract $=1572461$ or http://dx.doi.org/10.2139/ssrn.1572461

An, Y. (2017). Measuring earnings quality over time. International Journal of Economics and Financial Issues, 7(3), 82-87.

An, Y. (2019). An empirical study on the relationship between foreign investors and earnings quality. Research in World Economy, 10(3), 99-107. https://doi.org/10.5430/rwe.v10n3p99

Asiri, B., \& Alzeera, H. (2013). Is the Saudi stock market efficient? A case of weakform efficiency. Research Journal of Finance and Accounting, 4(6), 35-48. 
Assad, N. F., \& Alshurideh, M. T. (2020). Financial reporting quality, audit quality, and investment efficiency: Evidence from GCC economies. Waffen-und Kostumkunde Journal, 14(3),194-208.

Aziz, O. G., \& Mishra, A. V. (2016). Determinants of FDI inflows to Arab economies. The Journal of International Trade \& Economic Development: An International and Comparative Review, 25(3), 325-356.

https://doi.org/10.1080/09638199.2015.1057610.

Ball, R., \& Shivakumar, L. (2005). Earnings quality in U.K. private firms;

Comparative loss recognition. Journal of Accounting and Economics, 39(1), 83128. https://doi.org/10.1016/j.jacceco.2004.04.001

Ball, R., Robin, A., \& Wu, J. S. (2003). Incentives versus standards: Properties of accounting income in four East Asian countries. Journal of Accounting and Economics, 36(1), 235-270. https://doi.org/10.1016/j.jacceco.2003.10.003

Barth, M. E., Beaver, W. H., \& Landsman, W. R. (2001). The relevance of the value relevance literature for financial accounting standard setting: Another view. Journal of Accounting and Economics, 31(1-3), 77-104. https://doi.org/10.1016/S0165-4101(01)00019-2

Barton, J., \& Simko, P. J. (2002). The balance sheet as an earnings management constraint. The Accounting Review, 77(Supplement), 1-27. https://www.jstor.org/stable/3203322

Basu, S. (1997). The conservatism principle and the asymmetric timeliness of earnings. Journal of Accounting and Economics, 24(1), 3-37. https://doi.org/10.1016/-s0165-4101(97)00014-1

Bell, A., Fairbrother, M., \& Jones, K. (2019). Fixed and random effects models: Making an informed choice. Quality \& Quantity, 53(2), 1051-1074. https://doi.org/10.1007/s1113 5-018-0802-x

Ben-Naser, H., Boubakri, N., \& Cosset, J.-C. (2015). Earnings quality in privatized firms: The role of state and foreign owners. Journal of Accounting \& Public Policy, 34(4), 392-416. https://doi.org/10.1016/j.jaccpubpol.2014.12.003

Bissessur, S. W. (2008). Earnings quality and earnings management: The role of accounting accruals [Unpublished doctoral dissertation). Amsterdam Business School Research Institute Rotterdam: Thela, Amsterdam.

Bloomfield, M. J., Gerakos, J., \& Kovrijnykh, A. (2017). Accrual reversals and cash conversion. Chicago Booth Research Paper, 14-29. http://dx.doi.org/10.2139/ssrn.2495610

Callao, S., Cimini, R., \& Jarne, J. I. (2016). Value relevance of accounting figures in presence of earnings management. Are enforcement and ownership diffusion 
really enough? Journal of Business Economics and Management, 17(6), 12861299. https://doi.org/10.3846/16111699.2016.1203816

Chan, K., Chan, L. K., Jegadeesh, N., \& Lakonishok, J. (2006). Earnings quality and stock returns. the Journal of Business, 79(3), 1041-1082.

https://doi.org/10.1086/500669

Chandrapala, P., (2013). The value relevance of earnings and book value: The importance of ownership concentration and firm size. Journal of

Competitiveness, 5(2), 98-107. https://doi.org/10.7441/joc.2013.02.07

Cheng, C. S. A., \& Li, S. (2014). Does income smoothing improve earnings informativeness? - A comparison between the US and China markets. China Accounting and Finance Review, 16(2), 128-147.

https://doi.org/10.7603/s40570-014-0010-6

Choi, J. J., Lam, K. C. K., Sami, H., \& Zhou, H. (2013). Foreign ownership and information asymmetry. Asia-Pacific Journal of Financial Studies, 42(2), 141166. https://doi.org/10.1111/ajfs.12010

Dechow, P. M., \& Dichev, I. D. (2002). The quality of accruals and earnings: The role of accrual estimation errors. The Accounting Review, 77(S-1), 35-59. https://doi.org/10.2308/accr.2002.77.s-1.35.

Dechow, P., Ge, W., \& Schrand, C. (2010). Understanding earnings quality: A review of the proxies, their determinants and their consequences. Journal of Accounting and Economics, 50, 344-401. https://doi.org/10.1016/j.jacceco.2010.09.001

Desai, H., Krishnamurthy, S., \& Venkataraman, K. (2006). Do short sellers target firms with poor earnings quality? Evidence from earnings restatements. Review of Accounting Studies, 11(1), 71-90. https://doi.org/10.1007/s11142-006-6396-X

Dichev, I., Graham, J., Harvey, C. R., \& Rajgopal, S. (2013). Earnings quality: Evidence from the field. Journal of Accounting and Economics, 56(1-2) supplement 1, 1-33. https://doi.org/10.1016/j.jacceco.2013.05.004.

Dobre, F., Brad, L., \& Ciobanu, R. (2015). Timely loss recognition and the value relevance of the Romanian listed companies considering the IFRS approach. Accounting and Management Information Systems, 14(4), 732-747.

Elheddad, M. M. (2018). What determines FDI inflow to MENA countries? Empirical study on Gulf countries: Sectorial level analysis. Research in International Business and Finance, 44(C), 332-339. https://doi.org/10.1016/j.ribaf.2017.07.101

Entwistle, G. M., \& Phillips, F. (2003). Relevance, reliability, and the earnings quality debate. Issues in Accounting Education, 18(1), 79-92.

https://doi.org/10.2308/iace.2003.18.1.79 
Ezat, A., Mahmoud, N., Mohamed, A. M. F., Abulaila, M., Jaradat, S. A. N., Amin, A. Z., \& Abdelmajeed, S. H. (2019). Measuring earnings quality in Saudi Arabia insurance companies. International Journal of Applied Engineering Research, 14(23), 4294-4309. https://www.ripublication.com/ijaer19/ijaerv14n23_10.pdf

Ferreira, M. A., Matos, P., Pereira, J. P., \& Pires, P. (2017). Do locals know better? A comparison of the performance of local and foreign institutional investors.

Journal of banking and Finance. 82(September), 151-164.

https://doi.org/10.1016/j.jbankfin.2017.06.002

Francis, J., LaFond, R., Olsson, P. M., \& Schipper, K. (2004). Costs of equity and earnings attributes. The Accounting Review, 79(4), 967-1010. https://doi.org/10.2308/accr.2004.79.4.967

Greene, W. H. (2000). Econometric Analysis (4th ed.). Macmillan.

Hair, J. F., Black, W. C., Babin, B. J., Anderson, R. E, \& Tatham, R. L. (2006) Multivariate data analysis (6th ed.). Prentice Hall.

Hamdan, A. M. M., Abzakh, M. H., \& Al-Ataibi, M. H. (2011). Factors influencing the level of accounting conservatism in the financial statements. International Business Research, 4(3), 145-155. https://doi.org/10.5539/ibr.v4n3p145

Hellström, K. (2006). The value relevance of financial accounting information in a transition economy: The case of the Czech Republic. European Accounting Review, 15(3), 325-349. https://doi.org/10.1080/09638180600916242

Holt, P. (2013). Earnings quality as measured by predictability of reported earnings. Advances in Business Research, 4(1), 49-53.

Hussein, M. A. (2009). Impacts of foreign direct investment on economic growth in the Gulf Cooperation Council (GCC) countries. International Review of Business Research Papers, 5(3), 362-376.

Jiang, L., \& Kim, J. B. (2004). Foreign equity ownership and information asymmetry: Evidence from Japan. Journal of International Financial Management and Accounting, 15(3), 185-211. https://doi.org/10.1111/j.1467-646X.2004.00107.x

Jung, B. C., Lee, D., Shin, I., \& Yuen, C. Y. D. (2020). Foreign equity ownership and income smoothing. Journal of International Accounting Research, 19(2), 141-162. https://doi.org/10.2308/jiar-19-514.

Kadri, M. H., Abdul Aziz, R., \& Ibrahim, M. K. (2009). Value relevance of book value and earnings: Evidence from two different financial reporting regimes. Journal of Financial Reporting \& Accounting, 7(1), 1-16. https://doi.org/10.1108/19852510980000638

Khalil, M., Ozkanc, A., \& Yildiz, Y. (2020). Foreign institutional ownership and demand for accounting conservatism: Evidence from an emerging market. 
Review of Quantitative Finance and Accounting, 55, 1-27. https://doi.org/ https://doi.org/10.1007/s11156-019-00834-3

Khayat, S. H. (2020). Determinants of international foreign portfolio investment flows to GCC countries: An empirical evidence. International Journal of Business and Management, 15(10), 51-59. https://doi.org/10.5539/ijbm.v15n10p51

Kim, Y., Li, S., Pan, C. H., \& Zuo, L. (2013). The role of accounting conservatism in the equity market: Evidence from seasoned equity offerings. The Accounting Review, 88(2), 1327-1356. https://dx.doi.org/10.2139/ssrn.2170179

Kumar, A., \& Singh, D. (2013). Testing weak from stock market efficiency on Muscat Securities market: Oman. Skyline Business Journal, IX(1), 9-13.

Leal, L. T. Y., Girão, L. F. D. P., Lucena, W. G. L., \& Martins, V. G. (2017).

Persistence, value relevance, and accruals quality in extreme earnings and cash flow situations. Mackenzie Management Review, 18(3), 203-231 http://dx.doi.org/10.1590/1678-69712017/administracao.v18n3p203-231

Lee, J., \& Kim, E. (2019). Foreign monitoring and predictability of future cash flow. Sustainability, 2019, 11, 4832, 1-22. https://doi.org/10.3390/su11184832

Leuz, C. D., Nanda, D., \& Wysocki, P. (2003). Earnings management and investor protection: An international comparison. Journal of Financial economics, 69(3), 505-527. https://doi.org/10.1016/S0304-405X(03)00121-1.

Licerán-Gutiérrez, A., \& Cano-Rodríguez, M. (2020). Using partial least squares in archival accounting research: An application to earnings quality measuring. Spanish Journal of Finance and Accounting/Revista Española de Financiación y Contabilidad, 49(2), 143-170.

https://doi.org/10.1080/02102412.2019.1608705

Lyimo, G. D. (2014). Assessing the measures of quality of earnings from India. European Journal of Accounting Auditing and Finance Research, 2(6), 17-28.

Maditinos, D. I., Šević, Ž., Stankevičienè, J., \& Karakoltsidis, N. (2013). Earnings response coefficients in the Greek market. Journal of Business Economics and Management, 14(2), 414-431. https://doi.org/10.3846/16111699.2012.758168.

Marashdeh, H., \& Shrestha, M. B. (2008). Efficiency in emerging markets - Evidence from the Emirates securities market. European Journal of Economics, Finance and Administrative Sciences, 12, 143-150.

Matsumoto, D. A. (2002). Management's incentives to avoid negative earnings surprises. The Accounting Review, 77(3), 483-514. https://doi.org/10.2308/accr.2002.77.3.483

Menicucci, E. (2020). Earnings quality: Definitions, measures, and financial reporting. Palgrave Pivot publisher. 
Mirza, A., Malek, M., \& Abdul-Hamid, M. A. (2019). Value relevance of financial reporting: Evidence from Malaysia. Cogent Economics \& Finance, 7(1), 1651623, 1-19. https://doi.org/10.1080/23322039.2019.1651623

Naif, A. T., \& Ali, H. M. (2019). Saudi Arabia regulations on corporate governance. International Journal of Asian Social Science, 9(2), 229-239. https://doi.org/10.18488/journal.1.2019.92.229.239

Nezlobin, A., Sloan, R., \& Giedt, J. Z. (2019). Measuring accruals quality: A theoretical and empirical evaluation. https://ssrn.com/abstract=3301083

Nuruzzaman, M. (2013). Political, economics and Saudi military intervention in Bahrain. Journal of Contemporary Asia, 43(2), 363-378. https://doi.org/10.1080/00472336.2012.759406

Okoro, E. C., \& Ofor, T. N. (2019). Determinants of accounting earnings surprises in an emerging economy. International Journal of Innovative Finance and Economics Research, 7(4), 29-44.

Pauceanu, A. M. (2016). Foreign investment promotion analysis in Sultanate of Oman: The case of Dhofar governorate. International Journal of Economics and Financial Issues, 6(2), 392-401.

Penman, S., \& Zhang, X. J. (2002). Accounting conservatism, the quality of earnings and stock returns. The Accounting Review, 77(2), 237-264. https://www.jstor.org/stable/3068897

Perotti, P., \& Wagenhofer, A. (2014). Earnings quality measures and excess returns. Journal of Business Finance \& Accounting, 41(5) \& (6), 545-571. https://doi.org/10.1111/jbfa.12071.

Pradhan, P. K. (2017). Qatar crisis and challenges to GCC unity. Liberal Studies, 2(2), 241-254.

Radzi, S. N., Mohd, J., Islam, M. A., \& Ibrahim, S. (2011). Earning quality in public listed companies: A study on Malaysia exchange for securities dealing and automated quotation. International Journal of Economics and Finance, 3(2), 233-244. https://doi.org/10.5539/ijef.v3n2p233

Ragab, A. A., \& Omran, M. M. (2006). Accounting information, value relevance, and investors' behavior in the Egyptian equity market. Review of Accounting and Finance, 5(3), 279-297. https://doi.org/10.1108/14757700610686444

Rountree, B., Weston, J. P., \& Allayannis, G. (2008). Do investors value smooth performance? Journal of Financial Economics, 90(3), 237-251. https://doi.org/10.1016/j.jfineco.2008.02.002

Salman, M. H. A., \& Nobanee, H. (2019). Recent developments in corporate governance codes in the GCC region. Research in World Economy, 10(30), 108126. https://doi.org/10.5430/rwe.v10n3p108 
Sari, E., \& Sarumpaet, S. (2019). Conservatism under IFRS In Indonesia. International Journal of Scientific \& Technology Research, 8(6), 16-21.

Sen, K. (2009). Earnings surprise and sophisticated investor preferences in India. Journal of Contemporary Accounting \& Economics, 5(1), 1-19. https://doi.org/10.1016/j.jcae.2008.11.001

Shehata, N. F. (2015). Development of corporate governance codes in the GCC: An overview. Corporate Governance, 15(3), 315-338. https://doi.org/10.1108/cg11-2013-0124

Shin, H., \& Oh, H. (2017). The effect of accruals quality on the association between voluntary disclosure and information asymmetry in Korea. The Journal of Applied Business Research, 33(1), 223-236. https://doi.org/10.19030/jabr.v33i1.9892

Shubita, M. F. (2015). The impact of income smoothing on earnings quality in emerging markets: Evidence from GCC markets. Journal of Accounting in Emerging Economies, 5(3), 299-324. https://doi.org/10.1108/jaee-04-2011-0011 Vanlalhriati, C., \& Singh, E. N. (2015). Descriptive statistics in business research. International Journal of Advanced Research, 3(6), 1409-1415

Vo, X. V., \& Chu, T. K. H. (2019). Do foreign shareholders improve corporate earnings quality in emerging markets? Evidence from Vietnam. Cogent Economics \& Finance, Economics \& Finance, 7: 1698940.

https://doi.org/10.1080/23322039.2019.1698940

Wang, Z. (2014). Measuring investors' assessment of earnings persistence: Do investors see through smoothed earnings? Review of Quantitative Finance and Accounting, 42(4), 691-708. https://doi.org/10.1007/s11156-013-0358-8

Watts, R. L. (2003a). Conservatism in accounting part I: Explanations and implications. Accounting Horizons, 17(3), 207-221. https://doi.org/10.2139/ssrn.414522

Zhong, Y., \& Li, W. (2017). Accounting conservatism: A literature review. Australian Accounting Review, 27(2), 195-213. https://doi.org/10.1111/auar.12107

Dr. Mawih Kareem Al Ani is currently an associate professor of accounting at the College of Commerce and Business Administration in Dhofar University in Oman. His research interests focus on earnings quality, conservatism and audit quality. He has published articles in international journals, such as Borsa Istanbul Review, International Journal of Economic, Management and Accounting, Business: Theory and Practice, Future Business Journal and many other indexed journals. 